\title{
Riverine supply to the eastern Mediterranean during last interglacial sapropel S5 formation: A basin-wide perspective
}

\author{
Jiawang $\mathrm{Wu}^{\mathrm{a}, \mathrm{b}, *}$, Amalia Filippidi ${ }^{\mathrm{a}}$, Gareth R. Davies ${ }^{\mathrm{c}}$, Gert J. de Lange ${ }^{\mathrm{a}, \mathrm{b}}$ \\ ${ }^{a}$ Department of Earth Sciences-Geochemistry, Faculty of Geosciences, Utrecht University, Princetonplein 9, 3584 CC Utrecht, The Netherlands \\ ${ }^{\mathrm{b}}$ State Key Laboratory of Marine Geology, Tongii University, Siping 1239, 200092 Shanghai, China \\ ${ }^{\mathrm{c}}$ Department of Petrology, Faculty of Earth and Life Sciences, Vrije Universiteit (VU) Amsterdam, De Boelelaan 1085, 1081 HV Amsterdam, The Netherlands
}

\section{A R T I C L E I N F O}

Editor: Michael E. Böttcher

Keywords:

Sapropel S5

Eastern Mediterranean Sea

Provenance

Radiogenic isotopes

Major elements

Rare earth elements

\begin{abstract}
A B S T R A C T
Organic-rich sapropel sediments were repeatedly deposited in the eastern Mediterranean Sea (EMS), in response to insolation-driven freshwater forcing. However, the exact freshwater sources and causal associated paleoclimate-related processes remain unresolved. Sapropel S5, formed during the insolation maximum of the last interglacial, is one of the most intensely developed sapropels of the Late-Quaternary. Here, detrital sediments of sapropel S5 obtained from 8 cores, together with 13 EMS surface samples, are analyzed for major elements, rare earth elements (REE), and Sr and Nd isotopes. This permits a basin-wide investigation of the source and distribution of river-borne material to the EMS for sapropel S5, and its comparison to the present-day and the Holocene sapropel S1 period. During the sapropel S5, there was minor Saharan dust input. The marked east-west geochemical gradient in S5 detrital sediments across the EMS is therefore attributed to mixing between fluvial contributions, being Nile discharge, Aegean/Adriatic riverine inputs, and Libyan-Tunisian paleodrainage fluxes. The offshore distribution of Nile sediments during sapropel S5 was comparable to those during S1 and the present. The Nile sediment contribution appears to be only dominant for the Levantine Basin, decreasing to negligible values south of Crete. This rather limited sediment delivery, despite inferred increased runoff during S5, is related to denser vegetation cover on the Ethiopian Highlands. By contrast, small rivers around the Aegean (and Adriatic) Sea brought large amounts of detrital material into the EMS. This is particularly noticeable around Crete and the northern Ionian Sea. The enhanced riverine input is probably due to strong precipitation seasonality over the northern EMS borderlands, particularly for the early phase of the last interglacial maximum. Furthermore, there are substantial fluvial contributions from the Libyan-Tunisian margin to the Ionian Sea sediments, in particular during the last part of sapropel S5. The inferred river-borne material was transported via paleodrainage systems reactivated by intensified monsoon precipitation, and derived from central-Saharan mountains. Compared to sapropel S1, these S5-related paleodrainage fluxes were not only stronger, but also had a more predominant provenance from eastern rather than western Libya. In addition, a similar, averaged endmember of Saharan dust sources is revealed by REE signatures.
\end{abstract}

\section{Introduction}

The eastern Mediterranean Sea (EMS) is a semi-enclosed basin surrounded by catchment areas characterized by different climate regimes (Tzedakis, 2007; Magny et al., 2013; Rohling et al., 2015) and rock compositions (Krom et al., 1999a; Weldeab et al., 2002a; Revel et al., 2010; Wu et al., 2016). Moreover, the EMS has a dynamic thermohaline circulation (Pinardi and Masetti, 2000; Rohling et al., 2015), making it particularly sensitive to changes in the hydrological cycle. This sensitivity is best documented by the rhythmic deposition of organic-rich sapropel units, which is at an astronomically controlled cyclicity throughout the last 13.5 million years (see review by Rohling et al., 2015). Sapropels occur only during the precession-forced summer insolation maxima in the northern hemisphere, coupled with increased seasonal contrast and river runoff (Rossignol-Strick, 1983; BarMatthews et al., 2000; Lourens, 2004; Zhao et al., 2012). The enhanced freshwater and nutrients delivered by runoff stimulated a pronounced density stratification of the water column and an increased primary productivity in the surface waters. This ultimately led to anoxic deepwater conditions and sapropel formation in the EMS (e.g. RossignolStrick, 1983; De Lange and Ten Haven, 1983; Rohling, 1994; Emeis et al., 2000, 2003; Marino et al., 2007; De Lange et al., 2008).

\footnotetext{
* Corresponding author at: State Key Laboratory of Marine Geology, Tongji University, Siping 1239, 200092 Shanghai, China.

E-mail addresses: j.w.wu@uu.nl, jwwu@tongji.edu.cn (J. Wu).
} 


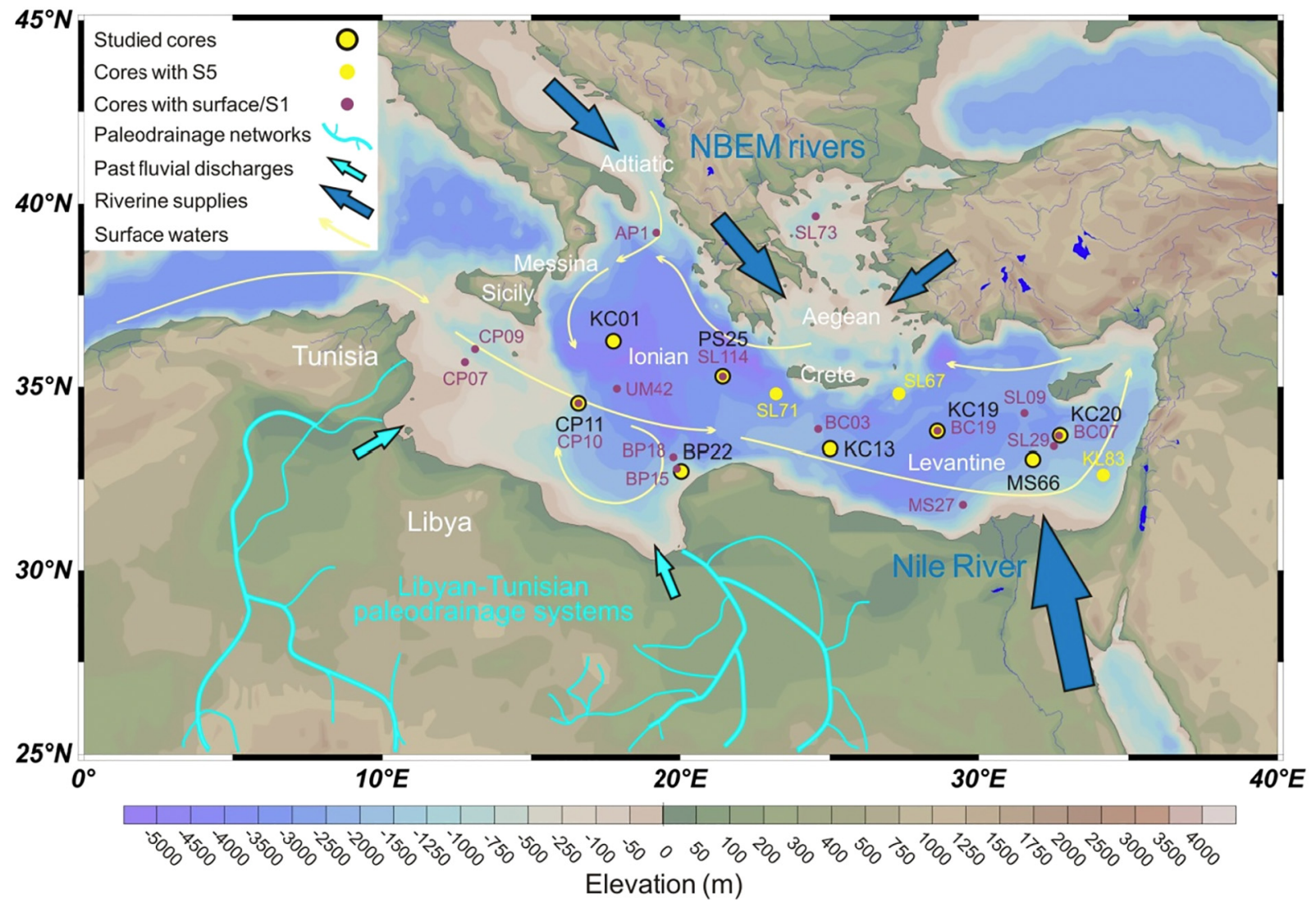

Fig. 1. Map of the eastern Mediterranean Sea (EMS) and adjacent areas, showing the locations of studied cores, and the auxiliary cores with samples analyzed and/or data used (Table 1). Paleodrainage networks derived from central Saharan mountains towards the wider North-African margin are outlined (Vörösmarty et al., 2000; Rohling et al., 2002; Paillou et al., 2009, 2012; Coulthard et al., 2013). Present-day perennial riverine discharges into the EMS are also indicated. Large-scale circulation of surface waters is after Pinardi and Masetti (2000).

Regardless of the relative importance of deep-water stagnation versus surface-ocean productivity, sapropel deposition can be viewed as directly related to freshwater forcing and its hydrographic response (Rohling, 1994; Emeis et al., 2003; Marino et al., 2007; Grelaud et al., 2012; Rohling et al., 2015). Indeed, using numerical models, physical oceanography studies have shown that with increasing freshwater forcing the strength of the deep-water stagnation is increased, and that changes in the source of freshwater modulate this effect (Myers et al., 1998; Myers, 2002). This is in agreement with the interplay between thermohaline circulation and deep-water oxygen consumption, as revealed by ocean-biogeochemical modeling (Stratford et al., 2000; Bianchi et al., 2006; Grimm et al., 2015). However, the exact freshwater sources and the controlling paleoclimatic processes are still debated, thereby urging to provide a strong justification.

\subsection{Circulation pattern and freshwater forcing}

An important characteristic of the present-day Mediterranean is its anti-estuarine circulation pattern. The surface inflow of relatively fresh, low-density water flows eastward with increasing salinity and in a counter-clockwise pathway (Fig. 1). Strong evaporation causes the Mediterranean to function as a concentration basin, converting the surface water into deeper outflow of salty, denser water (Pinardi and Masetti, 2000). Consequently, the aridity and, more generally speaking, the hydroclimate over the Mediterranean region, strongly influences the physical parameters of the surface waters (Rohling, 1994; Emeis et al., 2000, 2003; Marino et al., 2007). These include precipitation/ evaporation balance and changes in regional convection, all of which play a central role in the functioning of the thermohaline circulation (Myers et al., 1998; Myers, 2002; Rohling et al., 2015). In other words, there is a basin-averaged excess of evaporation (X) over total freshwater input (i.e. $\mathrm{X}=\mathrm{E}$ (evaporation) $-\mathrm{P}$ (precipitation) $-\mathrm{R}$ (runoff); $X>0$ ), in particular for the EMS (Rohling et al., 2015, and references therein).

Such pattern may have varied in the past, especially at times of sapropel formation. The spatial estimates for changes in paleo-freshwater forcing and consequent circulation pattern are mostly based on planktonic foraminiferal oxygen isotope $\left(\delta^{18} \mathrm{O}\right)$ data. Three different hypotheses exist for the Holocene sapropel S1 period suggesting that the present-day west-east surface-water salinity gradient was: 1) reversed to an estuarine-type condition (Thunell and Williams, 1989), 2) changed to a flat field, i.e. no gradient but not reversed (Kallel et al., 1997), and 3) similar to that of today but with a weaker gradient (Rohling and De Rijk, 1999). For an in-depth discussion of these hypotheses see Emeis et al. (2000). Specifically, in comparing singlespecies records only, Rohling and De Rijk (1999) suggested that the S1 salinity gradient reduced to $\sim 75 \%$ of its modern magnitude. This is consistent with simulations regarding changes in Mediterranean salinity and $\delta^{18} \mathrm{O}$, inferring that the S1 salinity gradient remained at $\sim 80 \%$ of its current value, in response to an $\mathrm{X}$ that decreased to $65 \%$ (Rohling, 1999). Numerical models of Mediterranean circulation show development of deep-water stagnation with a reduction in $\mathrm{X}$ to $<80 \%$ of its present-day value (Myers et al., 1998; Myers, 2002).

Although changes in freshwater balance can be reconstructed from foraminiferal $\delta^{18} \mathrm{O}$, such a spatial estimate has only been done for sapropel S1. More critically, this approach is complicated by the uncertainties in the use of salinity vs. $\delta^{18} \mathrm{O}$ relationships and different foraminiferal species (Rohling, 1999; Rohling and De Rijk, 1999), and it carries little provenance information which is crucial for the EMS. In fact, the former uncertainty is related to the runoff freshwater $\delta^{18} \mathrm{O}$ 
which in turn depends on its river system and provenance (e.g. altitude, latitude).

\subsection{Detrital sediment provenance and paleodrainage fluxes}

The EMS sediments contain distinct terrigenous detrital components, with aeolian and riverine origin, driven by competing climatic processes. A strong east-west gradient has been reported for the EMS sediments, with three main sediment provenances proposed (Venkatarathnam and Ryan, 1971; Krom et al., 1999a; Weldeab et al., 2002a; Klaver et al., 2015). This is due to mixing between two endmembers: "young and mafic" Nile sediment is diluted towards the west by "old and felsic" Saharan dust. Such a provenance pattern can generally explain the variability of sediment composition in the eastern part of the EMS, i.e. the Levantine Basin (e.g. Krom et al., 1999b; Wehausen and Brumsack, 2000; Ehrmann et al., 2007; Revel et al., 2010; Zhao et al., 2012). For the areas west of Crete, however, the system is much more complex. Besides the traditional two endmembers, a third component needs to be invoked, in particular for the Ionian Sea (e.g. Freydier et al., 2001; Weldeab et al., 2002b; Goudeau et al., 2013; Klaver et al., 2015; Wu et al., 2016). This has been related to fluvial contributions from the wider North-African margin, derived from reactivated paleodrainage systems during sapropel periods (Klaver et al., 2015; Wu et al., 2016, 2017), when a much diminished impact from Saharan dust could be detected (e.g. Weldeab et al., 2002b; Larrasoaña et al., 2003; Castañeda et al., 2009; Liu et al., 2012; Wu et al., 2017).

During sapropel times, intensified monsoon precipitation reactivated the fossil river/wadi systems along the wider North-African margin (Vörösmarty et al., 2000; Paillou et al., 2009, 2012; Coulthard et al., 2013). This not only provided green corridors that favored human dispersal (e.g. Castañeda et al., 2009; Drake et al., 2011; Hoffmann et al., 2016; Timmermann and Friedrich, 2016), but also transported substantial amounts of detrital material and freshwater to the EMS. Such runoff routes have been reported to function for a majority of the Quaternary sapropels, such as S1 (Krom et al., 1999b; Freydier et al., 2001; Wu et al., 2016, 2017), S5 (Rohling et al., 2002, 2004; Sangiorgi et al., 2006; Osborne et al., 2008, 2010), and S6 (Emeis et al., 2003). This scenario is supported by the reconstructed long-term dust records (Larrasoaña et al., 2003), and may also occur for the humid-climate episodes without sapropel deposition (Hoffmann et al., 2016). However, limited information is available on the origin, distribution, and intensity of this North-African paleodrainage contribution. This is partly because existing datasets do not adequately cover the Ionian Sea, and in particular lack information for the Libyan margin. This knowledge is very important as such paleodrainage fluxes and associated networks may have 1) constituted a considerable freshwater source for sapropel formation, 2) played a key role in the nonlinear feedbacks to insolation forcing, and 3) had a major influence on the human migrations out of Africa (c.f. Rohling et al., 2015; Wu et al., 2017).

\subsection{Sapropel $S 5$ and the last interglacial maximum}

Previous sapropel studies mainly focused on the most-recent, radiocarbon datable sapropel S1 in the Holocene (e.g. Emeis et al., 2000; Freydier et al., 2001; Reitz et al., 2006; Box et al., 2011; Hennekam et al., 2014; Filippidi et al., 2016). Although the general principles are similar, all individual sapropels show their own specific features (Rohling et al., 2015). Sapropel S5 is one of the most intensely developed of the Late Quaternary. It has elevated organic carbon $\left(\mathrm{C}_{\text {org }}\right)$, commonly $7-8 \%$ compared to $\sim 2 \%$ usually found in other sapropels, and lacks benthic fossils, which indicates persistent anoxia occurred below $300 \mathrm{~m}$ water-depth (e.g. Schmiedl et al., 2003; Rohling et al., 2004; Sangiorgi et al., 2006; Marino et al., 2007; Grelaud et al., 2012).

An important aim of this work is also to provide better analogues for the present-day climate. This is needed to comprehend paleoclimate variability to distinguish between natural climatic- and human inducedchanges. Sapropels S1 and S5 formed during insolation-driven monsoon maxima of the current (Holocene) and the last interglacial periods respectively. Both monsoon maxima were interrupted by a dry interlude of several centuries, with concomitant cooling over the Northern Borderlands of the Eastern Mediterranean (NBEM; i.e. Aegean and Adriatic regions) (e.g. S1: Emeis et al., 2000; Hennekam et al., 2014; Filippidi et al., 2016; S5: Rohling et al., 2002, 2004; Schmiedl et al., 2003; Scrivner et al., 2004). As a result, the period of sapropel S5 deposition in the EMS ( 128 to $121 \mathrm{ka}$ cal. BP; c.f. Rohling et al., 2015) last interglacial insolation maximum - Marine Isotope sub-Stage 5e (MIS 5e), has long been regarded as a potential analogue for the present (e.g. Kukla et al., 1997; Rohling et al., 2002; Marino et al., 2007). This period had a strong boreal summer insolation maximum, driven by the coincidence of a minimum in the precessional cycle with a distinct maximum in orbital eccentricity (Berger and Loutre, 1991). This superposition causes a more intensified African monsoon and associated northward migration of the tropical rainbelt. As a consequence, the freshwater flooding was stronger during sapropel S5 than during S1 (e.g. Rossignol-Strick, 1983; Bar-Matthews et al., 2000; Rohling et al., 2002, 2004).

\subsection{Geochemical proxies of provenance study}

Produced by long-lived radioactive decay, variations in $\mathrm{Sr}$ and $\mathrm{Nd}$ isotopes have been widely employed as tracer for the provenance of silicate detritus in marine sediments (e.g. Freydier et al., 2001; Weldeab et al., 2002a, 2002b; Revel et al., 2010; Box et al., 2011; Rodrigo-Gámiz et al., 2015; Van der Lubbe et al., 2016; Wu et al., 2016). It must be noted that yet, $\mathrm{Sr}$ isotopes tend to be affected by grain size, chemical weathering, and the potential barite-Sr remained in detrital fraction (Colin et al., 2006; Meyer et al., 2011). This emphasizes the joint use of $\mathrm{Sr}$ isotopes with $\mathrm{Nd}$ isotopes that have been proven to be a conservative provenance proxy.

Apart from radiogenic isotopes, major elements of detrital sediments can be applied to track changes in detrital supplies. In the Mediterranean basin, climatic-humid sapropel periods are characterized by higher $\mathrm{K} / \mathrm{Al}$ and $\mathrm{Mg} / \mathrm{Al}$ as well as lower $\mathrm{Ti} / \mathrm{Al}$ and $\mathrm{Zr} / \mathrm{Al}$ values, reflecting enhanced riverine relative to reduced aeolian fluxes; and vice versa for more arid conditions (e.g. Krom et al., 1999b; Wehausen and Brumsack, 2000; Sangiorgi et al., 2006; Scheuvens et al., 2013; Hennekam et al., 2014; Martinez-Ruiz et al., 2015; Wu et al., 2017). However, distinguishing between aeolian and fluvial sources based on certain elemental ratios alone is challenging, as eventually the terrigenous detrital minerals with similar elemental composition may be supplied by either river or dust (c.f. Martinez-Ruiz et al., 2015).

On the other hand, the rare earth elements (REE) could potentially be more robust and diagnostic for provenance characterization, because they are not fractionated from each other by most sedimentary processes (Nesbitt, 1979). REE are largely insoluble, and generally retained and concentrated within the weathering profile in secondary minerals. Once eroded, these soil minerals then faithfully record the REE signature of the parent material. REE concentrations also remain unaffected by most post-depositional processes (c.f. Nesbitt, 1979; Taylor and McLennan, 1985; Yang et al., 2002).

Specifically, the light REE (LREE, La-Sm) are relatively incompatible during magmatic crystallization; whereas due to the smaller ionic radii, the heavy REE (HREE, Gd-Lu) are not only more easily incorporated into the crystal structures of rock-forming minerals, but also selectively hosted by some igneous minerals (e.g. feldspars, hornblende, pyroxene, and zircon) (Taylor and McLennan, 1985). Consequently, the LREE/HREE ratio, often approximated by $\mathrm{La}_{N} / \mathrm{Yb}_{N}$ (i.e. ratio of La to $\mathrm{Yb}$ with normalization to chondrite; Boynton, 1985), is a useful fingerprint of source rock (e.g. Révillon et al., 2011; Wu et al., 2013). In addition, different from other REE, Eu in igneous processes can be reduced to $\mathrm{Eu}^{2+}$, and selectively removed compared to its 
Table 1

General information of the investigated cores over the eastern Mediterranean Sea.

\begin{tabular}{|c|c|c|c|c|c|}
\hline Core $^{a}$ & Corer/site ${ }^{\mathrm{b}}$ & Location & Water-depth & Cruise & Sample analyzed \& data source ${ }^{c}$ \\
\hline $\mathrm{CP} 11^{\mathrm{d}}$ & PC & $34^{\circ} 32.7^{\prime} \mathrm{N}, 16^{\circ} 34.0^{\prime} \mathrm{E}$ & $1501 \mathrm{~m}$ & RV Pelagia 2011 & Sapropel S5; Wu et al. (2017) \\
\hline KC01 & Site-B & $36^{\circ} 15.3^{\prime} \mathrm{N}, 17^{\circ} 44.3^{\prime} \mathrm{E}$ & $3643 \mathrm{~m}$ & RV Marion Dufresne 1991 & Sapropel S5 \\
\hline BP22 & PC & $32^{\circ} 42.7^{\prime} \mathrm{N}, 20^{\circ} 01.8^{\prime} \mathrm{E}$ & $438 \mathrm{~m}$ & RV Pelagia 2001 & Sapropel S5 \\
\hline PS25 & PC & $35^{\circ} 17.4^{\prime} \mathrm{N}, 21^{\circ} 24.8^{\prime} \mathrm{E}$ & $3304 \mathrm{~m}$ & RV Pelagia 2000 & Sapropel S5; Kraal et al. (2010) \\
\hline KC13 & Site-B & $33^{\circ} 19.4^{\prime} \mathrm{N}, 25^{\circ} 00.8^{\prime} \mathrm{E}$ & $2181 \mathrm{~m}$ & RV Marion Dufresne 1991 & Sapropel S5 \\
\hline KC19 & Site-C & $33^{\circ} 47.9^{\prime} \mathrm{N}, 28^{\circ} 36.5^{\prime} \mathrm{E}$ & $2750 \mathrm{~m}$ & RV Marion Dufresne 1991 & Sapropel S5; Passier et al. (1998) \\
\hline MS66 & PC & $33^{\circ} 01.9^{\prime} \mathrm{N}, 31^{\circ} 47.9^{\prime} \mathrm{E}$ & $1630 \mathrm{~m}$ & RV Pelagia 2004 & Sapropel S5; Boere et al. (2011) \\
\hline KC20 & Site-A & $33^{\circ} 40.6^{\prime} \mathrm{N}, 32^{\circ} 42.6^{\prime} \mathrm{E}$ & $882 \mathrm{~m}$ & RV Marion Dufresne 1991 & Sapropel S5 \\
\hline $\mathrm{CP} 07$ & $\mathrm{BC}$ & $35^{\circ} 40.5^{\prime} \mathrm{N}, 12^{\circ} 46.7^{\prime} \mathrm{E}$ & $275 \mathrm{~m}$ & RV Pelagia 2011 & Surface \\
\hline СР09 & $\mathrm{BC}$ & $36^{\circ} 02.2^{\prime} \mathrm{N}, 13^{\circ} 06.6^{\prime} \mathrm{E}$ & $524 \mathrm{~m}$ & RV Pelagia 2011 & Surface \\
\hline $\mathrm{CP} 10^{\mathrm{d}}$ & $\mathrm{BC}$ & $34^{\circ} 32.7^{\prime} \mathrm{N}, 16^{\circ} 34.0^{\prime} \mathrm{E}$ & $1501 \mathrm{~m}$ & RV Pelagia 2011 & Surface; Wu et al. $(2016,2017)$ \\
\hline $\mathrm{AP} 1^{\mathrm{d}}$ & GC & $39^{\circ} 13.0^{\prime} \mathrm{N}, 19^{\circ} 06.8^{\prime} \mathrm{E}$ & $811 \mathrm{~m}$ & RV Urania 1998 & Surface; Tachikawa et al. (2004) \\
\hline BP18 & $\mathrm{BC}$ & $33^{\circ} 06.0^{\prime} \mathrm{N}, 19^{\circ} 46.4^{\prime} \mathrm{E}$ & $1850 \mathrm{~m}$ & RV Pelagia 2001 & Surface \\
\hline BP15 & $\mathrm{BC}$ & $32^{\circ} 46.7^{\prime} \mathrm{N}, 19^{\circ} 52.6^{\prime} \mathrm{E}$ & $665 \mathrm{~m}$ & RV Pelagia 2001 & Surface \\
\hline SL114 ${ }^{\mathrm{d}}$ & $\mathrm{BC}$ & $35^{\circ} 17.2^{\prime} \mathrm{N}, 21^{\circ} 24.5^{\prime} \mathrm{E}$ & $3390 \mathrm{~m}$ & RV Logachev 1999 & Surface; Wu et al. (2016) \\
\hline $\mathrm{SL73}^{\mathrm{d}}$ & $\mathrm{BC}$ & $39^{\circ} 39.7^{\prime} \mathrm{N}, 24^{\circ} 30.7^{\prime} \mathrm{E}$ & $339 \mathrm{~m}$ & RV Logachev 1999 & Surface; Tachikawa et al. (2004) \\
\hline SL09 & $\mathrm{BC}$ & $34^{\circ} 17.2^{\prime} \mathrm{N}, 31^{\circ} 31.4^{\prime} \mathrm{E}$ & $2302 \mathrm{~m}$ & RV Logachev 1999 & Surface \\
\hline SL29 & $\mathrm{BC}$ & $33^{\circ} 23.4^{\prime} \mathrm{N}, 32^{\circ} 30.2^{\prime} \mathrm{E}$ & $1587 \mathrm{~m}$ & RV Logachev 1999 & Surface \\
\hline $\mathrm{BC} 07^{\mathrm{d}}$ & $\mathrm{BC}$ & $33^{\circ} 40.0^{\prime} \mathrm{N}, 32^{\circ} 40.0^{\prime} \mathrm{E}$ & $893 \mathrm{~m}$ & RV Marion Dufresne 1995 & Surface; Freydier et al. (2001) \\
\hline $\mathrm{BCO}^{\mathrm{d}}$ & $\mathrm{BC}$ & $33^{\circ} 22.5^{\prime} \mathrm{N}, 24^{\circ} 46.0^{\prime} \mathrm{E}$ & $2180 \mathrm{~m}$ & RV Marion Dufresne 1995 & Post-S1; Freydier et al. (2001) \\
\hline BC19 ${ }^{d}$ & $\mathrm{BC}$ & $33^{\circ} 47.9^{\prime} \mathrm{N}, 28^{\circ} 36.5^{\prime} \mathrm{E}$ & $2750 \mathrm{~m}$ & RV Marion Dufresne 1991 & Post-S1; Freydier et al. (2001) \\
\hline UM42 $2^{\mathrm{d}}$ & $\mathrm{BC}$ & $34^{\circ} 57.2^{\prime} \mathrm{N}, 17^{\circ} 51.8^{\prime} \mathrm{E}$ & $1375 \mathrm{~m}$ & & Freydier et al. (2001) \\
\hline MS27 $^{\mathrm{d}}$ & GC & $31^{\circ} 47.9^{\prime} \mathrm{N}, 29^{\circ} 27.3^{\prime} \mathrm{E}$ & $1389 \mathrm{~m}$ & & Revel et al. $(2010,2014)$ \\
\hline $\mathrm{SL71}^{\mathrm{e}}$ & GC & $34^{\circ} 48.6^{\prime} \mathrm{N}, 23^{\circ} 11.7^{\prime} \mathrm{E}$ & $2827 \mathrm{~m}$ & & Weldeab et al. (2002b) \\
\hline SL67 ${ }^{\mathrm{e}}$ & GC & $34^{\circ} 48.8^{\prime} \mathrm{N}, 27^{\circ} 17.8^{\prime} \mathrm{E}$ & $2157 \mathrm{~m}$ & & Weldeab et al. (2002b) \\
\hline $\mathrm{KL} 83^{\mathrm{e}}$ & GC & $32^{\circ} 36.9^{\prime} \mathrm{N}, 34^{\circ} 08.9^{\prime} \mathrm{E}$ & $1431 \mathrm{~m}$ & & Weldeab et al. (2002b) \\
\hline
\end{tabular}

a The appellation is referred to as core-name only (i.e. no corer/site) in the paper.

b BC: box core; GC: gravity core; PC: piston core (or with site indicated).

c Samples analyzed in this study; S5 samples are taken based on the stratigraphy frameworks in previous studies, otherwise after G.J. de Lange (unpublished data); The post-S1, late-Holocene samples are used to represent arid-climate condition as recent period.

d Published data of sapropel S1 are used.

e Published data of sapropel S5 are used.

neighbors (Taylor and McLennan, 1985). Accordingly, a positive Eu anomaly (Eu/Eu*) indicates mafic rocks, as does low values of LREE/ HREE and $\mathrm{La}_{\mathrm{N}} / \mathrm{Yb}_{\mathrm{N}}$; and vice versa (e.g. Moreno et al., 2006; Révillon et al., 2011; Wu et al., 2013; Dang et al., 2015). Despite these merits of REE fractionation pattern and associated parameters, unfortunately, only few relevant studies with REE data have been reported for EMS sediments.

In short, detailed knowledge of riverine supply to the EMS during sapropel S5 can contribute to a better understanding of sapropel formation, paleoclimate variability, and human migration. Here, we present a comprehensive and basin-wide study for the geochemical composition of detrital sediments of sapropel S5 and of surface samples. Our approach combines the use of major elements, REE, as well as $\mathrm{Sr}$ and $\mathrm{Nd}$ isotopes. Integrating our results with those from published and existing datasets (Table 1; Fig. 1), we investigate the influences of different riverine contributions for sapropel S5 at a basin-wide scale and make comparisons with the present-day and Holocene sapropel S1.

\section{Material and methods}

A total of 17 samples were obtained from sapropel S5 layers in 8 core-sites selected to give a geographical and bathymetric coverage of the EMS (Table 1; Fig. 1). The stratigraphic frameworks for these cores were generally established by foraminiferal $\delta^{18} \mathrm{O}$ and sapropel chronology (Passier et al., 1998; Lourens, 2004; Kraal et al., 2010; Boere et al., 2011; Wu et al., 2017) (Table 1). The samples were taken to represent the most typical sapropel conditions, based on $\mathrm{C}_{\text {org }}, \mathrm{Ba} / \mathrm{Al}$ criteria, and $\delta^{18} \mathrm{O}$ data (c.f. Bar-Matthews et al., 2000; De Lange et al., 2008; Rohling et al., 2015). Note that the foraminiferal surface-water $\delta^{18} \mathrm{O}$ data have two distinct peaks for sapropel S5 separated by an interruption of $\sim 1000$ years (Rohling et al., 2002, 2004). Accordingly, our S5 samples are differentiated between a lower S5a and an upper S5b interval. In addition to sapropel S5 samples, 11 surface sediments as well as 2 recent, late-Holocene samples from key-sites in the EMS were processed (Table 1; Fig. 1). This provides a refined base for the comparison between sapropel and non-sapropel periods.

All geochemical analyses were performed on the detrital, i.e. nonbiogenic, lithogenic sediment fraction. Following the protocol of Van Santvoort et al. (1996), freeze-dried, powdered bulk sediments were decarbonated by shaking in $1 \mathrm{M} \mathrm{HCl}$ for 4 and $12 \mathrm{~h}$. Subsequently, the residues were rinsed twice with deionized water, oven-dried at $80^{\circ} \mathrm{C}$, and finely ground for a routine three-step total digestion. Approximately $125 \mathrm{mg}$ of sample was digested in a mixture of $\mathrm{HF}-\mathrm{HClO}_{4}-\mathrm{HNO}_{3}$ and heated at $90^{\circ} \mathrm{C}$ in a gastight Teflon vessel for at least $12 \mathrm{~h}$. Afterward, the solution was evaporated at $160^{\circ} \mathrm{C}$ to near dryness, and the residue was then dissolved in $4.5 \% \mathrm{HNO}_{3}$ at $90^{\circ} \mathrm{C}$ (Reitz et al., 2006).

Major elements were measured by inductively coupled plasma optical emission spectroscopy (ICP-OES) on a Ciros Vision. The samples were further diluted to analyze trace elements including REE, using an $\mathrm{X}$-series II inductively coupled plasma mass spectrometry (ICP-MS). For both techniques analytical uncertainties were monitored by measuring blanks, duplicates, and international standards ISE 921 (Van Dijk and Houba, 2000) and MAG-1 (Govindaraju, 1994). For the reported data of major- and trace-elements, the accuracy is better than $6 \%$ and $8 \%$, and the precision better than $3 \%$ and $5 \%$, respectively.

A smaller selection of 10 samples, including one sapropel S5 sample for each core and two surface sediment samples, was used for isotopic analyses at the Vrije Universiteit (VU) Amsterdam. The Sr and Nd isotopes were separated using conventional ion exchange techniques, and measured on a Triton Plus thermal ionization mass spectrometers and a Neptune Plus multi-collector inductively coupled plasma mass spectrometry, respectively. The ${ }^{87} \mathrm{Sr} /{ }^{86} \mathrm{Sr}$ and ${ }^{143} \mathrm{Nd} /{ }^{144} \mathrm{Nd}$ ratios were corrected for mass fractionation by normalizing to ${ }^{86} \mathrm{Sr} /{ }^{88} \mathrm{Sr}=0.1194$ and ${ }^{146} \mathrm{Nd} /{ }^{144} \mathrm{Nd}=0.7219$, applying the exponential law. The isotopic ratios were reported relative to the standard NBS-SRM 987 $\left({ }^{87} \mathrm{Sr} /{ }^{86} \mathrm{Sr}=0.710245 ;\right.$ Thirlwall, 1991) and in-house $\mathrm{Nd}$ reference 
Table 2

$\mathrm{Sr}$ and Nd isotope compositions of detrital sediments of investigated cores.

\begin{tabular}{|c|c|c|c|c|c|c|c|}
\hline Core & Depth $(\mathrm{cm})$ & Sample type & Sr (ppm) & ${ }^{87} \mathrm{Sr} /{ }^{86} \mathrm{Sr}\left( \pm 2 \sigma \times 10^{-6}\right)^{\mathrm{a}}$ & $\mathrm{Nd}(\mathrm{ppm})$ & ${ }^{143} \mathrm{Nd} /{ }^{144} \mathrm{Nd}\left( \pm 2 \sigma \times 10^{-6}\right)^{\mathrm{b}}$ & $\varepsilon_{\mathrm{Nd}}{ }^{\mathrm{c}}$ \\
\hline CP11 & 391.25 & S5a & 138.0 & $0.715881(10)$ & 20.7 & $0.512011(13)$ & -12.2 \\
\hline KC01 & 880.25 & S5a & 99.5 & $0.719321(10)$ & 22.2 & $0.512050(10)$ & -11.4 \\
\hline BP22 & 222.25 & S5a & 117.5 & $0.717286(9)$ & 19.7 & $0.512002(12)$ & -12.4 \\
\hline PS25 & 485.75 & S5a & 139.9 & $0.711774(10)$ & 10.8 & $0.512108(13)$ & -10.3 \\
\hline KC13 & 367.75 & S5a & 122.7 & $0.713825(10)$ & 14.9 & 0.512129 (11) & -9.9 \\
\hline KC19 & 417.25 & S5a & 97.4 & $0.711629(11)$ & 10.0 & $0.512190(10)$ & -8.7 \\
\hline MS66 & 554.5 & S5a & 74.5 & 0.710249 (9) & 9.8 & $0.512372(15)$ & -5.2 \\
\hline KC20 & 322.25 & S5a & 81.9 & $0.710508(10)$ & 10.7 & $0.512273(10)$ & -7.1 \\
\hline СР07 & $0-0.5$ & Surface & 127.6 & $0.716435(10)$ & 15.2 & $0.511992(9)$ & -12.6 \\
\hline BP15 & $0-0.5$ & Surface & 146.0 & $0.718807(11)$ & 23.8 & $0.512006(17)$ & -12.3 \\
\hline
\end{tabular}

${ }^{\text {a }}$ Normalized to the NBS-SRM 987 value of ${ }^{87} \mathrm{Sr} /{ }^{86} \mathrm{Sr}=0.70525$ (Thirlwall, 1991).

b Normalized to the in-house reference material CIGO $\left({ }^{143} \mathrm{Nd} /{ }^{144} \mathrm{Nd}=0.511342\right)$, equivalent to a La Jolla value of $0.511852(\mathrm{Griselin}$ et al., 2001$)$.

${ }^{c} \varepsilon_{\mathrm{Nd}}=\left[\left({ }^{143} \mathrm{Nd} /{ }^{144} \mathrm{Nd}\right)\right.$ measured $/\left({ }^{143} \mathrm{Nd} /{ }^{144} \mathrm{Nd}\right)$ CHUR -1$] \times 10^{4}$, while CHUR (chondritic uniform reservoir) is 0.512638 (Jacobson and Wasserburg, 1980).

material CIGO $\left({ }^{143} \mathrm{Nd} /{ }^{144} \mathrm{Nd}=0.511342\right.$ equivalent to a La Jolla value of 0.511852; Griselin et al., 2001), respectively. The NBS-SRM 987 gave ${ }^{87} \mathrm{Sr} /{ }^{86} \mathrm{Sr}=0.710240 \pm 0.000016(2 \sigma, \mathrm{n}=11)$, and the CIGO yielded ${ }^{143} \mathrm{Nd} /{ }^{144} \mathrm{Nd}=0.511384 \pm 0.000014(2 \sigma, \mathrm{n}=7)$. The $2 \sigma$ reproducibility of Nd isotope measurements was also checked using an in-house standard CPI ( $8 \mathrm{ppm}, \mathrm{n}=3$ ). International reference material MAG-1 was repeatedly run through the entire analytical procedures $(n=3)$, yielding ${ }^{87} \mathrm{Sr} /{ }^{86} \mathrm{Sr}$ and ${ }^{143} \mathrm{Nd} /{ }^{144} \mathrm{Nd}$ ratios of $0.722653 \pm 0.000016$ and $0.512054 \pm 0.000007$, respectively. Within error these values are consistent with the average values measured at the same lab $\left({ }^{87} \mathrm{Sr} /{ }^{86} \mathrm{Sr}\right.$ : $0.722657 \pm 0.000028 ;{ }^{143} \mathrm{Nd} /{ }^{144} \mathrm{Nd}: 0.512070 \pm 0.000012$ ) (Meyer et al., 2011; Klaver et al., 2015; Van der Lubbe et al., 2016). Total procedural blanks were negligible in all cases. $\mathrm{Nd}$ isotope compositions are expressed as: $\varepsilon_{\mathrm{Nd}}=\left[\left({ }^{143} \mathrm{Nd} /{ }^{144} \mathrm{Nd}\right)\right.$ measured $/\left({ }^{143} \mathrm{Nd} /{ }^{144} \mathrm{Nd}\right)$ CHUR -1$] \times 10^{4}$, while CHUR (chondritic uniform reservoir) is 0.512638 (Jacobsen and Wasserburg, 1980).

\section{Results}

The $\mathrm{Sr}$ and $\mathrm{Nd}$ isotopes on detrital sediments determined are reported in Table 2. The major element and REE (i.e. rare earth elements) data are given in Tables 3 and 4, respectively.

\subsection{Sr and Nd isotopes}

There is a generally inverse relationship between $\mathrm{Sr}$ and Nd isotope ratios and a clear east-west gradient for sapropel S5 detrital sediments (Fig. 2). The lowest ${ }^{87} \mathrm{Sr} /{ }^{86} \mathrm{Sr}$ and highest $\varepsilon_{\mathrm{Nd}}$ values occur in the Levantine Basin (KL83, KC20, MS66, and KC19), moderate values for the areas around the Island of Crete (SL67, KC13, SL71, and PS25), and the highest ${ }^{87} \mathrm{Sr} /{ }^{86} \mathrm{Sr}$ and lowest $\varepsilon_{\mathrm{Nd}}$ ratios in the Ionian Sea (PS25, BP22, KC01, and CP11). Compared to the EMS surface sediments, the overall domain of sapropel S5 samples tends towards a lower ${ }^{87} \mathrm{Sr} /{ }^{86} \mathrm{Sr}$ and higher $\varepsilon_{\mathrm{Nd}}$ signature. Note that an updated, integrated dataset of EMS surface sediments is provided and regionally grouped to better indicate the present-day situation (Fig. 2) (see Supplementary material).

\subsection{Major elements}

Two distinct segments of sapropel S5 (S5a and S5b; Rohling et al., 2004) were analyzed for elemental data. Following a recent study of Wu et al. (2017), a ternary diagram of $\mathrm{Ti}, \mathrm{K}$, and $\mathrm{Mg}$ contents is employed to distinguish detrital input. The major-element ternary diagram (Fig. 3) is made as follows: 1) Al-normalized ratios are used to limit the minimum and maximum values for each component, i.e. Ti/Al (0.05-0.08), K/Al (0.12-0.30), and $\mathrm{Mg} / \mathrm{Al}(0.11-0.23) ; 2)$ three relative values are then determined for each sample, and proportionally recalculated to make a sum of $100 \%$; 3 ) the respective fractions are plotted accordingly. Note that the pattern is identical whether using Al-normalization or not.
Table 3

Major elemental ratios of detrital sediments of investigated cores.

\begin{tabular}{|c|c|c|c|c|c|}
\hline \multirow[t]{2}{*}{ Core } & Depth & Sample & $\mathrm{Ti} / \mathrm{Al}$ & $\mathrm{K} / \mathrm{Al}$ & $\mathrm{Mg} / \mathrm{Al}$ \\
\hline & $(\mathrm{cm})$ & type & $(\mathrm{mg} / \mathrm{g})$ & $(\mathrm{mg} / \mathrm{g})$ & $(\mathrm{mg} / \mathrm{g})$ \\
\hline CP11 & 383.75 & S5b & 58.2 & 250 & 168 \\
\hline CP11 & 387.25 & S5a & 58.6 & 251 & 151 \\
\hline CP11 & 391.25 & S5a & 58.2 & 255 & 151 \\
\hline КС01 & 875.75 & S5b & 56.0 & 260 & 158 \\
\hline КС01 & 880.25 & S5a & 52.9 & 256 & 147 \\
\hline BP22 & 214.75 & S5b & 70.1 & 256 & 187 \\
\hline BP22 & 222.25 & S5a & 69.7 & 266 & 155 \\
\hline PS25 & 464.25 & S5b & 67.1 & 284 & 228 \\
\hline PS25 & 487.75 & S5a & 56.2 & 277 & 213 \\
\hline KC13 & 337.25 & S5b & 61.3 & 258 & 212 \\
\hline KC13 & 367.75 & S5a & 61.6 & 258 & 213 \\
\hline KC19 & 397.75 & S5b & 68.2 & 225 & 220 \\
\hline KC19 & 417.25 & S5a & 62.3 & 200 & 210 \\
\hline MS66 & 539.50 & S5b & 71.6 & 128 & 120 \\
\hline MS66 & 554.50 & S5a & 66.4 & 128 & 127 \\
\hline КС20 & 309.25 & S5b & 78.4 & 178 & 159 \\
\hline KC20 & 322.25 & S5a & 71.3 & 163 & 153 \\
\hline СР07 & $0-0.5$ & Surface & 69.6 & 275 & 131 \\
\hline СР09 & $0-0.5$ & Surface & 61.9 & 220 & 126 \\
\hline $\mathrm{CP} 10^{\mathrm{a}}$ & $0-0.5$ & Surface & 61.1 & 248 & 126 \\
\hline AP1 & $0-0.5$ & Surface & 58.2 & 261 & 161 \\
\hline BP18 & $0-0.5$ & Surface & 72.7 & 268 & 140 \\
\hline BP15 & $0-0.5$ & Surface & 68.9 & 265 & 152 \\
\hline SL114 & $0-0.5$ & Surface & 66.9 & 250 & 160 \\
\hline SL73 & $0-0.5$ & Surface & 52.6 & 258 & 170 \\
\hline SL09 & $0-0.5$ & Surface & 76.9 & 187 & 188 \\
\hline SL29 & $0-0.5$ & Surface & 88.5 & 177 & 143 \\
\hline BC07 & $0-0.5$ & Surface & 86.0 & 169 & 146 \\
\hline BC03 & 5.60 & Post-S1 & 71.0 & 256 & 186 \\
\hline BC19 & 3.75 & Post-S1 & 75.2 & 239 & 163 \\
\hline Saharan dust ${ }^{\mathrm{b}}$ & & Endmember & 81.1 & 223 & 143 \\
\hline Nile sediment ${ }^{\mathrm{b}}$ & & Endmember & 155 & 105 & 175 \\
\hline Aegean river ${ }^{c}$ & & Endmember & 60.0 & 300 & 400 \\
\hline Adriatic river $^{\mathrm{d}}$ & & Endmember & 49.6 & 317 & 150 \\
\hline Libya/Tunisia $^{\mathrm{a}}$ & & Endmember & 54.6 & 238 & 172 \\
\hline $\mathrm{UCC}^{\mathrm{e}}$ & & & 37.3 & 349 & 164 \\
\hline
\end{tabular}

${ }^{\text {a }}$ Data from Wu et al. (2017); Libya/Tunisia refers to the calculated endmember of Libyan-Tunisian paleodrainage fluxes therein.

b Data from Krom et al. (1999a, 1999b), reported as average values.

c Data from Wehausen and Brumsack (2000), estimated values are taken.

d Average values of $\mathrm{Ti} / \mathrm{Al}$ and $\mathrm{K} / \mathrm{Al}$ from Dolenec et al. (1998), the detrital $\mathrm{Mg} / \mathrm{Al}$ ratio is estimated after Wehausen and Brumsack (2000) and Wu et al. (2017).

Cores KC20 and MS66 (and KC19) located in the Levantine Basin have the highest Ti contents, especially for S5b samples (Fig. 3). For the cores around the Island of Crete, KC19, KC13, and PS25 samples show relatively high $\mathrm{Mg}$ contents. The samples of the Ionian Sea (CP11, BP22, and KC01) are characterized by relatively high K contents. Notably, 
Table 4

Rare earth element (REE) concentrations (ppm) and fractionation parameters of detrital sediments of investigated cores.

\begin{tabular}{|c|c|c|c|c|c|c|c|c|c|c|c|c|c|c|c|c|c|c|c|}
\hline Core & Depth $(\mathrm{cm})$ & Sample type & $\mathrm{La}$ & $\mathrm{Ce}$ & $\operatorname{Pr}$ & $\mathrm{Nd}$ & $\mathrm{Sm}$ & $\mathrm{Eu}$ & $\mathrm{Gd}$ & $\mathrm{Tb}$ & Dy & Ho & $\mathrm{Er}$ & $\mathrm{Tm}$ & $\mathrm{Yb}$ & $\mathrm{Lu}$ & $\mathrm{Eu} / \mathrm{Eu}^{* \mathrm{a}}$ & $\mathrm{La}_{\mathrm{N}} / \mathrm{Yb}_{\mathrm{N}}{ }^{\mathrm{a}, \mathrm{b}}$ & LREE/HREE ${ }^{\mathrm{a}, \mathrm{b}}$ \\
\hline CP11 & 383.75 & S5b & 30.2 & 56.9 & 5.47 & 18.8 & 2.79 & 0.56 & 2.57 & 0.32 & 1.94 & 0.38 & 1.20 & 0.19 & 1.27 & 0.20 & 0.644 & 16.04 & 4.994 \\
\hline CP11 & 387.25 & S5a & 31.9 & 59.9 & 5.71 & 19.6 & 2.94 & 0.58 & 2.58 & 0.33 & 2.03 & 0.39 & 1.25 & 0.20 & 1.32 & 0.21 & 0.649 & 16.32 & 5.083 \\
\hline CP11 & 391.25 & S5a & 33.1 & 62.0 & 5.99 & 20.7 & 3.11 & 0.69 & 2.94 & 0.36 & 2.18 & 0.42 & 1.34 & 0.21 & 1.43 & 0.22 & 0.695 & 15.61 & 4.853 \\
\hline KC01 & 875.75 & S5b & 35.6 & 66.8 & 6.34 & 21.7 & 3.21 & 0.75 & 3.03 & 0.36 & 2.16 & 0.42 & 1.35 & 0.22 & 1.43 & 0.22 & 0.731 & 16.77 & 5.140 \\
\hline KC01 & 880.25 & S5a & 37.3 & 70.5 & 6.60 & 22.2 & 3.20 & 0.61 & 2.93 & 0.35 & 2.17 & 0.43 & 1.40 & 0.22 & 1.49 & 0.23 & 0.611 & 16.83 & 5.312 \\
\hline BP22 & 214.75 & S5b & 27.4 & 49.3 & 5.22 & 18.9 & 3.15 & 0.66 & 2.95 & 0.40 & 2.43 & 0.46 & 1.41 & 0.22 & 1.46 & 0.23 & 0.661 & 12.69 & 3.914 \\
\hline BP22 & 222.25 & S5a & 28.7 & 51.7 & 5.46 & 19.7 & 3.25 & 0.69 & 3.06 & 0.42 & 2.55 & 0.48 & 1.49 & 0.24 & 1.58 & 0.25 & 0.672 & 12.23 & 3.866 \\
\hline PS25 & 464.25 & S5b & 30.1 & 56.2 & 5.81 & 20.9 & 3.49 & 0.71 & 3.14 & 0.43 & 2.56 & 0.48 & 1.49 & 0.23 & 1.54 & 0.24 & 0.654 & 13.19 & 4.120 \\
\hline PS25 & 487.75 & S5a & 15.1 & 29.1 & 3.02 & 10.8 & 1.72 & 0.34 & 1.56 & 0.19 & 1.15 & 0.22 & 0.71 & 0.11 & 0.78 & 0.12 & 0.641 & 13.13 & 4.380 \\
\hline KC13 & 337.25 & S5b & 24.1 & 44.1 & 4.49 & 15.9 & 2.57 & 0.65 & 2.40 & 0.31 & 1.92 & 0.37 & 1.16 & 0.19 & 1.24 & 0.19 & 0.797 & 13.10 & 4.160 \\
\hline KC13 & 367.75 & S5a & 22.7 & 41.4 & 4.24 & 14.9 & 2.43 & 0.59 & 2.21 & 0.29 & 1.81 & 0.35 & 1.10 & 0.17 & 1.17 & 0.18 & 0.776 & 13.03 & 4.168 \\
\hline KC19 & 397.75 & S5b & 16.0 & 29.0 & 3.10 & 11.2 & 1.87 & 0.41 & 1.71 & 0.24 & 1.49 & 0.28 & 0.87 & 0.14 & 0.94 & 0.15 & 0.700 & 11.49 & 3.738 \\
\hline KC19 & 417.25 & S5a & 14.9 & 25.9 & 2.81 & 10.0 & 1.68 & 0.40 & 1.55 & 0.22 & 1.42 & 0.28 & 0.87 & 0.14 & 0.94 & 0.15 & 0.749 & 10.75 & 3.525 \\
\hline MS66 & 539.50 & S5b & 16.2 & 25.1 & 2.87 & 10.2 & 1.81 & 0.47 & 1.78 & 0.28 & 1.84 & 0.36 & 1.12 & 0.18 & 1.21 & 0.19 & 0.799 & 9.044 & 2.901 \\
\hline MS66 & 554.50 & S5a & 15.8 & 24.0 & 2.78 & 9.79 & 1.75 & 0.51 & 1.72 & 0.27 & 1.79 & 0.35 & 1.08 & 0.17 & 1.17 & 0.18 & 0.891 & 9.093 & 2.894 \\
\hline KC20 & 309.25 & S5b & 20.5 & 34.7 & 3.72 & 13.3 & 2.31 & 0.56 & 2.19 & 0.33 & 2.15 & 0.41 & 1.27 & 0.20 & 1.35 & 0.21 & 0.766 & 10.23 & 3.268 \\
\hline KC20 & 322.25 & S5a & 16.8 & 27.3 & 3.02 & 10.7 & 1.89 & 0.49 & 1.86 & 0.29 & 1.88 & 0.37 & 1.14 & 0.18 & 1.24 & 0.19 & 0.796 & 9.127 & 2.975 \\
\hline СР07 & $0-0.5$ & Surface & 22.2 & 42.4 & 4.67 & 15.2 & 2.46 & 0.44 & 2.03 & 0.29 & 1.90 & 0.38 & 1.25 & 0.19 & 1.37 & 0.20 & 0.598 & 10.85 & 4.022 \\
\hline СР09 & $0-0.5$ & Surface & 31.6 & 58.1 & 6.47 & 21.0 & 3.22 & 0.53 & 2.60 & 0.37 & 2.37 & 0.47 & 1.58 & 0.23 & 1.67 & 0.24 & 0.557 & 12.72 & 4.503 \\
\hline CP10 & $0-0.5$ & Surface & 34.4 & 65.8 & 7.11 & 22.8 & 3.53 & 0.58 & 2.84 & 0.40 & 2.53 & 0.51 & 1.67 & 0.25 & 1.78 & 0.26 & 0.561 & 13.07 & 4.614 \\
\hline AP1 & $0-0.5$ & Surface & 28.9 & 53.8 & 6.01 & 19.8 & 3.10 & 0.51 & 2.59 & 0.36 & 2.38 & 0.48 & 1.64 & 0.24 & 1.75 & 0.25 & 0.555 & 11.15 & 4.083 \\
\hline BP18 & $0-0.5$ & Surface & 30.2 & 58.8 & 6.60 & 22.3 & 3.87 & 0.67 & 3.27 & 0.49 & 3.10 & 0.60 & 1.92 & 0.29 & 2.05 & 0.30 & 0.579 & 10.29 & 3.612 \\
\hline BP15 & $0-0.5$ & Surface & 33.6 & 64.1 & 7.34 & 23.8 & 4.05 & 0.70 & 3.36 & 0.48 & 3.03 & 0.59 & 1.89 & 0.28 & 1.98 & 0.28 & 0.576 & 11.45 & 4.023 \\
\hline SL114 & $0-0.5$ & Surface & 26.7 & 49.8 & 5.63 & 18.5 & 3.06 & 0.53 & 2.57 & 0.36 & 2.28 & 0.45 & 1.48 & 0.22 & 1.54 & 0.22 & 0.580 & 11.70 & 4.083 \\
\hline SL73 & $0-0.5$ & Surface & 19.2 & 36.5 & 4.17 & 14.3 & 2.53 & 0.48 & 2.11 & 0.29 & 1.85 & 0.35 & 1.15 & 0.19 & 1.22 & 0.18 & 0.634 & 10.64 & 3.743 \\
\hline SL09 & $0-0.5$ & Surface & 19.3 & 36.0 & 4.10 & 13.7 & 2.36 & 0.45 & 2.08 & 0.32 & 2.14 & 0.42 & 1.39 & 0.21 & 1.51 & 0.22 & 0.626 & 8.645 & 3.217 \\
\hline SL29 & $0-0.5$ & Surface & 19.8 & 38.8 & 4.21 & 14.1 & 2.55 & 0.52 & 2.32 & 0.36 & 2.39 & 0.47 & 1.55 & 0.24 & 1.67 & 0.24 & 0.655 & 7.974 & 3.010 \\
\hline BC07 & $0-0.5$ & Surface & 18.9 & 34.8 & 4.02 & 13.5 & 2.44 & 0.49 & 2.20 & 0.34 & 2.26 & 0.44 & 1.45 & 0.22 & 1.57 & 0.23 & 0.648 & 8.157 & 3.018 \\
\hline ВC03 & 5.60 & Post-S1 & 28.9 & 54.6 & 6.27 & 21.1 & 3.64 & 0.61 & 3.11 & 0.45 & 2.91 & 0.57 & 1.85 & 0.28 & 1.97 & 0.29 & 0.555 & 9.880 & 3.581 \\
\hline BC19 & 3.75 & Post-S1 & 27.8 & 52.1 & 5.94 & 20.1 & 3.48 & 0.61 & 3.03 & 0.44 & 2.87 & 0.56 & 1.82 & 0.28 & 1.97 & 0.29 & 0.579 & 9.521 & 3.469 \\
\hline \multicolumn{3}{|c|}{ Saharan soil ${ }^{\mathrm{c}}$} & 47.5 & 102 & 12.0 & 49.5 & 7.50 & 1.25 & 9.00 & 1.25 & 7.50 & 1.50 & 3.50 & $<0.5$ & 4.00 & $<0.5$ & 0.465 & 8.006 & 2.603 \\
\hline \multicolumn{3}{|c|}{ Nile mud ${ }^{\mathrm{d}}$} & 34.4 & 74.1 & 9.80 & 36.8 & 8.21 & 2.18 & 7.65 & 1.34 & 7.13 & 1.37 & 4.20 & 0.64 & 4.09 & 0.60 & 0.841 & 5.667 & 2.186 \\
\hline \multicolumn{3}{|l|}{$\mathrm{UCC}^{\mathrm{e}}$} & 30.0 & 64.0 & 7.10 & 26.0 & 4.50 & 0.88 & 3.80 & 0.64 & 3.50 & 0.80 & 2.30 & 0.33 & 2.20 & 0.32 & 0.651 & 9.194 & 3.275 \\
\hline
\end{tabular}

${ }^{\text {a }}$ With normalization to chondrite (Boynton, 1985); $\mathrm{Eu} / \mathrm{Eu}^{*}=\mathrm{Eu}_{\mathrm{N}} /\left(\mathrm{Sm}_{\mathrm{N}} \times \mathrm{Gd}_{\mathrm{N}}\right)^{1 / 2}$.

b Ratio of LREE (light REE, La-Sm) to HREE (heavy REE, Gd-Lu), often approximated by the ratio of $\mathrm{La}_{\mathrm{N}} / \mathrm{Yb}_{\mathrm{N}}$.

c Data from Moreno et al. (2006), average values of central-Sahara desert samples (Hoggar Massif and Chad Basin).

d Data from Padoan et al. (2011), average values of main Nile muds are reported.

e Average upper continental crust (Taylor and McLennan, 1985).

there is a Mg-rich trend for cores CP11 and BP22, with higher $\mathrm{Mg} / \mathrm{Al}$ values for S5b than S5a samples. A similar pattern is also observed for the surface/recent sediments, such as BC07, SL29, and SL09 in the Levantine Basin, BC19, BC03 and SL73 for the areas around Crete, and SL114, AP1, BP15, BP18, CP10, CP09 and CP07 for the Ionian Sea. Compared to the sapropel S5 detrital sediments, the surface samples are characterized by relatively high $\mathrm{Ti}$ and, a somewhat higher $\mathrm{K}$ value (Fig. 3).

\subsection{Rare earth elements}

The REE contents of the EMS samples are all depleted relative to the average upper continental crust (UCC) (Taylor and McLennan, 1985) (Fig. 4). With normalization to UCC, the REE patterns of sapropel S5 samples exhibit a greater enrichment of LREE (i.e. light REE, La-Sm) from east to west. In addition to the LREE enrichment, the UCC-normalized data are characterized by relatively homogenous HREE (i.e. heavy REE, Gd-Lu) contents but more heterogeneous middle REE contents. The latter is associated with variable Eu anomalies (Fig. 4a). The overall pattern of the recent sediments is similar to that of sapropel S5 samples, but with a less evident east-west change in LREE enrichment relative to HREE, and weaker Eu anomalies (Fig. 4b).

Variations in the UCC-normalized REE patterns (Fig. 4) are diagnostic of mafic vs. felsic source areas (Fig. 5). A negative Eu anomaly $\left(\mathrm{Eu} / \mathrm{Eu}^{*}\right)$, and a high ratio of the light to heavy REE (i.e. LREE/HREE, $\mathrm{La}_{\mathrm{N}} / \mathrm{Yb}_{\mathrm{N}}$ ), both indicate the felsic-rock nature of detrital sediment (Taylor and McLennan, 1985). Note that the REE parameters are all normalized to chondrite (Boynton, 1985). The good negative correlations between these two parameters are associated with by a strong east-west gradient throughout the EMS. In a plot of $\mathrm{La}_{\mathrm{N}} / \mathrm{Yb}_{\mathrm{N}}$ vs. $\mathrm{Eu} / \mathrm{Eu}^{*}, r^{2}$ is 0.48 and 0.53 for sapropel S5 and recent sediment, respectively (Fig. 5a); and in the LREE/HREE vs. Eu/Eu* $r^{2}$ is 0.51 and 0.56 for sapropel S5 and recent sediment, respectively (Fig. 5b). The arrays of surface sediments are distinctly different from those of sapropel S5, but the provenance pattern described above is also observed for sapropel S5 and surface samples (Fig. 5). It must be note that the lines connecting the S5 and recent sediments for each site/area all extrapolate to the same signature (Fig. 5).

\section{Discussion}

The surface EMS sediments and the surface geology of catchment areas over the EMS have been investigated by clay mineralogy, elemental geochemistry, and radiogenic isotopes (c.f. Venkatarathnam and Ryan, 1971; Krom et al., 1999a; Weldeab et al., 2002a; BoutRoumazeilles et al., 2007; Ehrmann et al., 2007; Revel et al., 2010; Goudeau et al., 2013; Scheuvens et al., 2013; Rodrigo-Gámiz et al., 2015; Martinez-Ruiz et al., 2015). In the Levantine Basin, a simple mixing model between Nile sediment and Saharan dust is sufficient to explain the variability of detrital supplies, in terms of clay minerals, elemental ratios, and Sr-Nd isotopes (Venkatarathnam and Ryan, 1971; Krom et al., 1999b; Freydier et al., 2001; Revel et al., 2010). The Sr-Nd isotope data suggest that the Late-Quaternary sediments deposited in the areas around Crete are a mixture of Saharan dust and Aegean/Nile river-borne materials (Weldeab et al., 2002b; Ehrmann et al., 2007); while the Aegean and Nile contributions cannot be differentiated using 


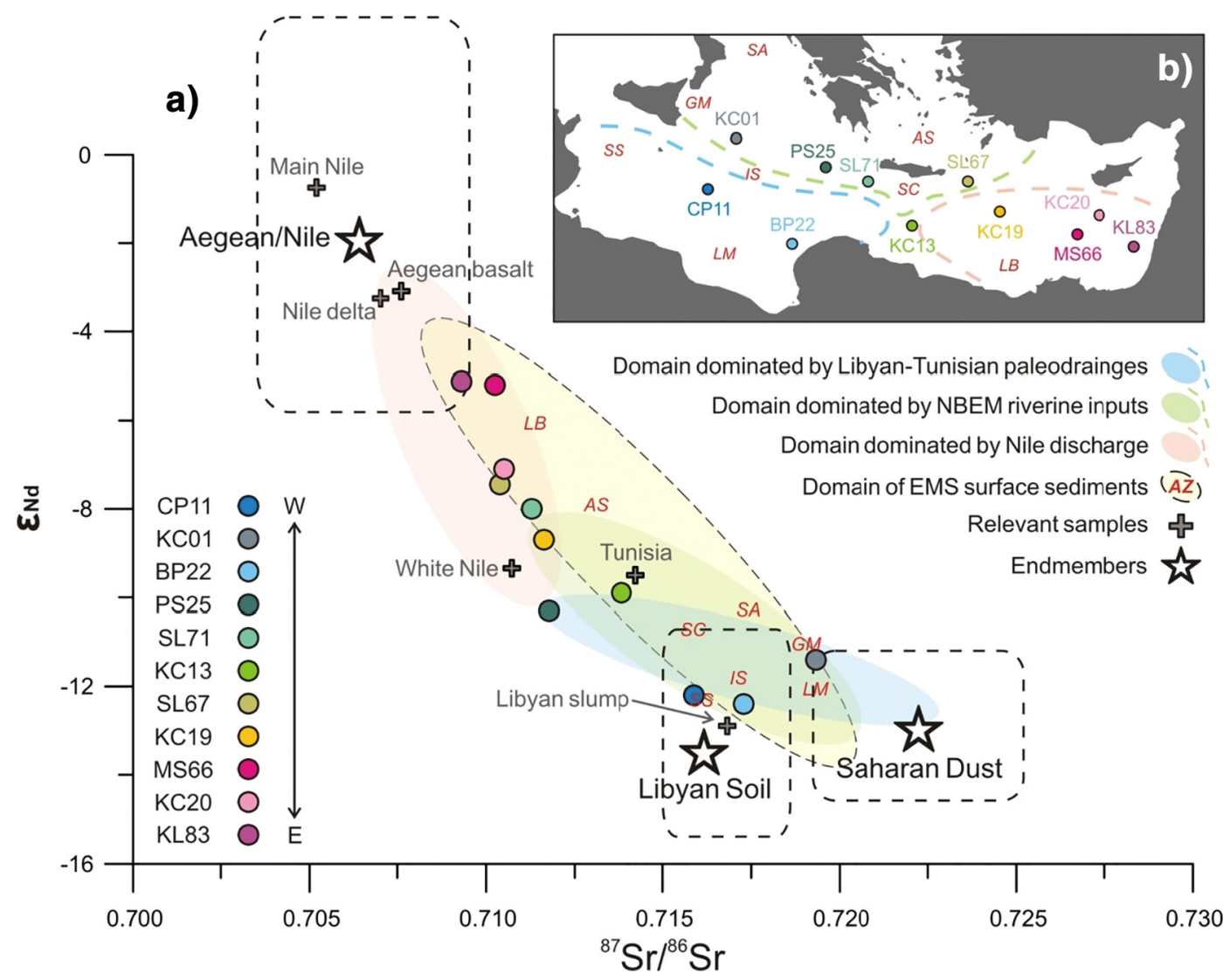

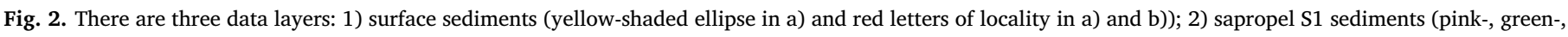

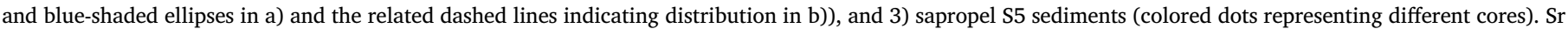

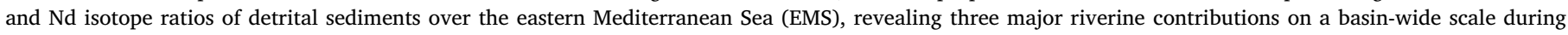

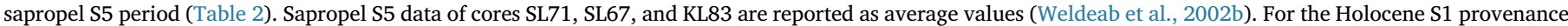

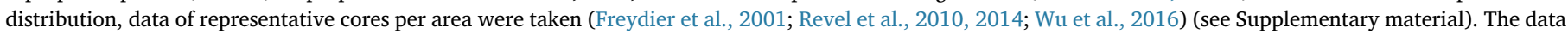

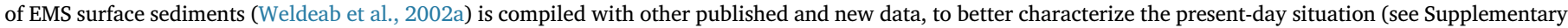

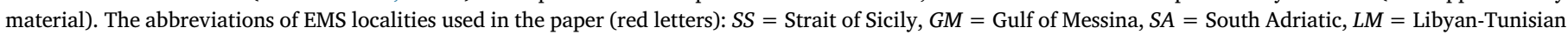

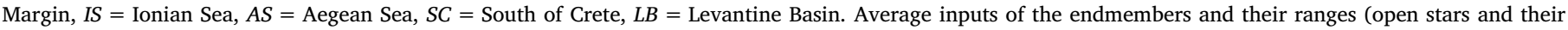

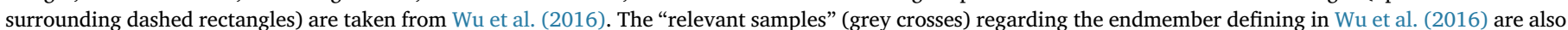

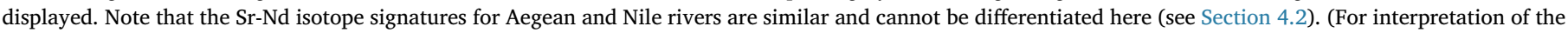
references to colour in this figure legend, the reader is referred to the web version of this article.)

these isotopes alone (Weldeab et al., 2002a, 2002b; Wu et al., 2016). For the Ionian Sea, a three-endmember mixing system based on Sr-Nd isotopes adequately attributes the sediment provenance to Saharan dust, NBEM/Nile riverine inputs, and fluvial/shelf-derived fluxes from the Libyan-Tunisian margin (Wu et al., 2016).

These systematics are fully corroborated by a multiproxy study using detrital elements, clay minerals, and grain size end-member modeling (Wu et al., 2017, and references therein). The study reveals that Saharan dust is characterized by high Ti and kaolinite, the NBEM riverine inputs have relatively high $\mathrm{K}$, illite and chlorite, and the Libyan-Tunisian paleodrainage fluxes are characterized by high $\mathrm{Mg}$ and smectite.

Although REE composition can give robust constraints for provenance determination, only a few REE dataset exist for the Mediterranean, and most of these are on the western basin (Freydier et al., 2001; Moreno et al., 2006; Padoan et al., 2011; Révillon et al., 2011). In this study we combine the use of Sr and Nd isotopes, major elements, and REE. The results are discussed relative to riverine contributions and the main provenance areas.

\subsection{Relative aeolian and riverine contributions during sapropel S5}

Today, deposition of Saharan dust is a dominant ( $>90 \%$ ) detrital component to sediments in the Eastern Mediterranean basin (Guerzoni et al., 1999), and its distribution is approximately uniform in an east-west direction (Krom et al., 1999a; Rutten et al., 2000). Compared to EMS surface sediments, representing typical arid climate conditions, sapropel S5 samples have a distinctly lower ${ }^{87} \mathrm{Sr} /{ }^{86} \mathrm{Sr}$ and a slightly higher $\varepsilon_{\mathrm{Nd}}$ isotopic composition (Figs. 2 and 6). This difference could be due to contributions of Saharan dust being lower or those of riverine influx being higher during the humid, sapropel S5 period compared to the present. However, it has also been suggested that decreased aeolian and increased riverine fluxes occurred simultaneously at times of sapropel deposition (e.g. Krom et al., 1999b; Wehausen and Brumsack, 2000; Freydier et al., 2001; Liu et al., 2012; Wu et al., 2016). Our data of sapropel S5 show different isotopic signals for different provenance areas (Fig. 2). In addition to the uniformly reduced Saharan dust, such differences in spatial variation indicate that riverine supplies must have varied spatially and possibly with different temporal pacing.

Similar patterns are recorded by the major- and trace-element data (Fig. 3). Compared to the sapropel S5 detrital sediments, the EMS surface sediments are more affected by the Saharan dust inputs, characterized by relatively high $\mathrm{Ti}$, and to a lesser extent, $\mathrm{K}$ (e.g. compare KC20-S5 to BC07/SL29 and PS25-S5 to SL114 from the same sites, respectively, at Erathostenes Seamount and mid-Ionian). Indeed, $\mathrm{Ti}$ principally resides in heavy minerals and is enriched in modern Saharan 


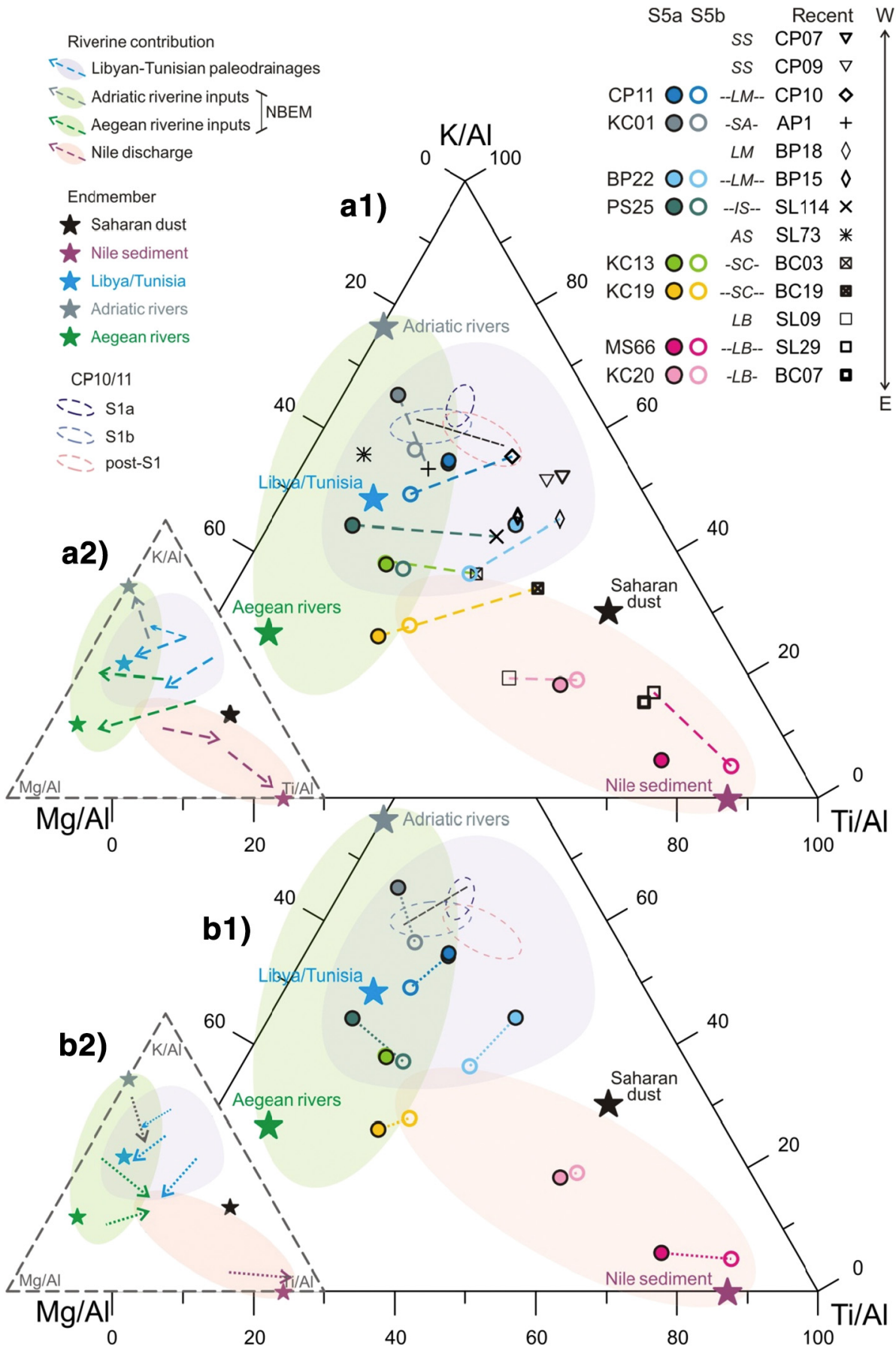

Fig. 3. Ternary diagram for major elements in the detrital fraction of sapropel S5 and recent sediments (Table 3). Sapropel S5 samples are differentiated between S5a and S5b (see Section 2). a1) Colored dashed-lines between recent and S5 samples for the same sites/areas show the differences from arid to humid climatic conditions. Note that the longest lines are used regardless of S5a or S5b sample, to represent the largest hydroclimate changes. The fields of major riverine contributions (shaded areas) are outlined, with associated endmembers (colored stars) (for sources see Table 3). In sub-plot a2), the colored arrows indicate the direction of increasing riverine contributions for each area from arid/recent to humid/S5 period, and for CP10/11 also for recent to S1. b1) Colored dotted-lines between S5a and S5b samples for each site/area show the hydroclimate changes within sapropel S5. In sub-plot b2), the colored arrows indicate the changes in riverine contributions for each area from S5a to S5b intervals, and for CP10/11 also from S1a to S1b. The S5a to S5b change points towards more enhanced riverine contributions for all southern EMS borderlands, and towards more reduced contributions for the northern borderlands. The S1a to S1b shift for core CP10/11 (Wu et al., 2017) is similar to that for S5a to S5b. For abbreviations of EMS localities see caption of Fig. 2. For details of diagram methodology see Section 3.2. aerosols, allowing the $\mathrm{Ti} / \mathrm{Al}$ ratio to be widely used as a proxy for Saharan dust (e.g. Wehausen and Brumsack, 2000; Lourens et al., 2001). Illite, usually enriched in $\mathrm{K}$, is one of the main clay minerals of Saharan dust (Guerzoni et al., 1999; Zhao et al., 2012; see also Wu et al., 2017). By contrast, the composition of sapropel S5 samples reflects reduced dust and enhanced riverine input, for each area with a different provenance signature. This is clearly observed in Fig. 3a, where for each site/area the difference between recent and S5 composition is illustrated with an arrow (i.e. away from the Saharan endmember, and towards their respective riverine endmember). This difference between arid- and humid-climatic conditions thus corresponds with different riverine supplies.

The overall REE pattern for surface sediments is similar to that for sapropel S5 samples, but with a more restricted enrichment of LREE relative to HREE, and with weaker Eu anomalies (Fig. 4). These data correspond with a much higher contribution of Saharan dust to the present-day sediments (Weldeab et al., 2002b; Larrasoaña et al., 2003; Castañeda et al., 2009; Liu et al., 2012). A higher Saharan dust contribution to surface sediments has subdued the signals of the relatively low recent riverine inputs, causing a lower east-west LREE fractionation and a lower Eu anomaly. Moreover, REE-derived parameters (i.e. $\mathrm{Eu} / \mathrm{Eu}^{*}, \mathrm{La}_{\mathrm{N}} / \mathrm{Yb}_{\mathrm{N}}$, and LREE/HREE) are consistently different between sapropel S5 and surface samples, showing the significant impact of Saharan dust today (Moreno et al., 2006) (Fig. 5). Notably, extrapolations from the $\mathrm{S} 5$ and recent sediments for the same sites/areas all point to the same composition, representing the similar, averaged Saharan endmember (Fig. 5). Taken together, the sapropel S5 samples have more varied REE patterns than recent sediments. This reflects the contributions from different riverine sources.

The spatial pattern of different riverine contributions also occurs 


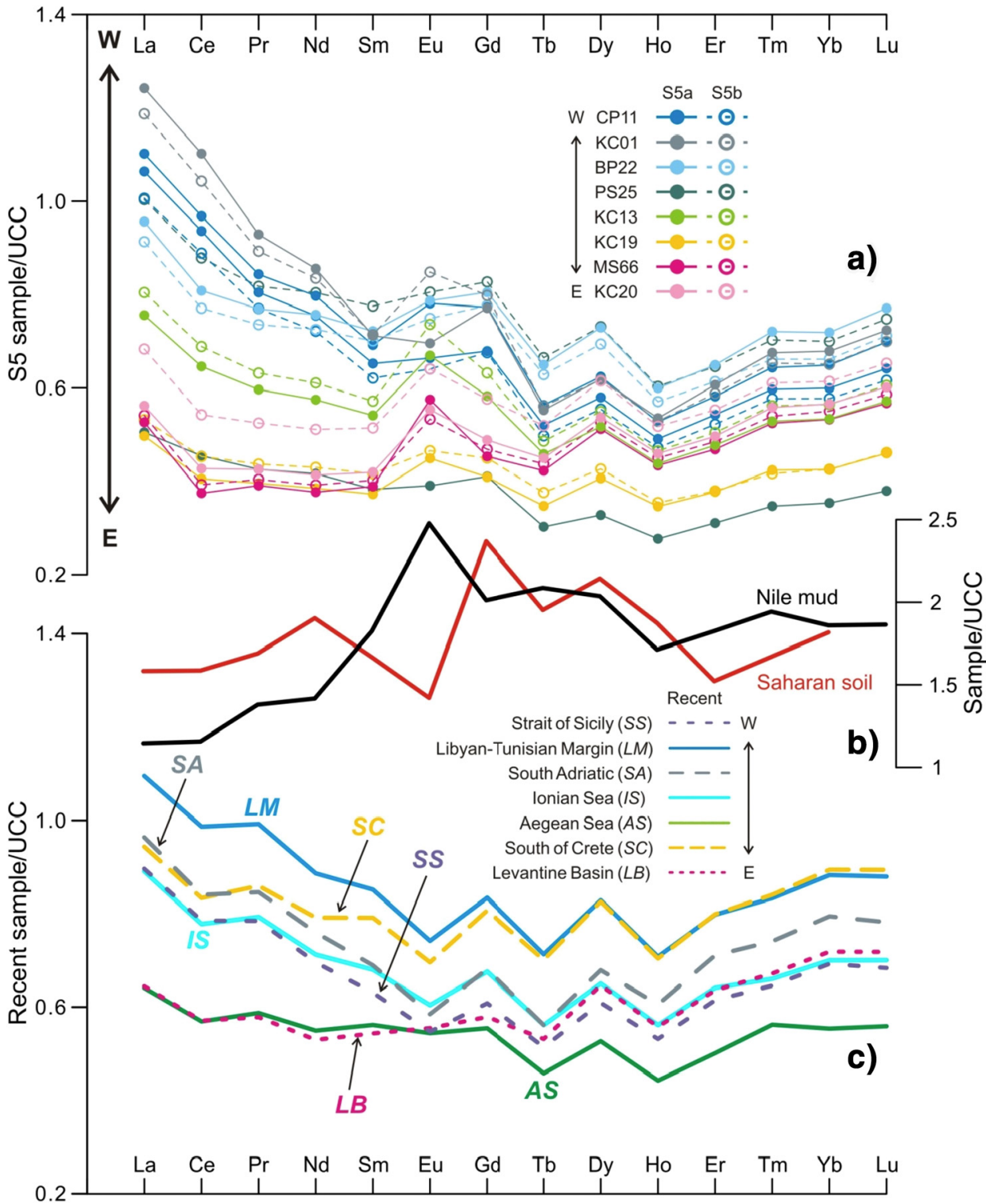

Fig. 4. REE (i.e. rare earth elements) fractionation patterns with normalization to upper continental crust (UCC) (Taylor and McLennan, 1985) for a) sapropel S5 and c) recent detrital sediments over the eastern Mediterranean Sea (EMS), in comparison to b) those of Saharan soil (Moreno et al., 2006) and Nile muds (Padoan et al., 2011) (Table 4). Sapropel S5 samples are differentiated between S5a and S5b (see Section 2 ). Note that for the recent samples, data are averaged for the main provenance areas. For the EMS sediments, there is a strong east-west gradient of light REE (LREE, La-Sm) enrichment, with a relatively homogenous heavy REE (HREE, Gd-Lu). The UCC-normalized data are characterized by a heterogeneous pattern for the middle REE, especially with variable Eu anomalies. The observed characteristics are more pronounced for sapropel S5 than surface samples. Taken together, these indicate the control of Nile discharge for the eastern EMS, the impact of Saharan dust for the climatic arid, recent period, and that the provenance of the western EMS (Ionian Sea) is characterized by a more prominent LREE enrichment and negative Eu anomaly. during sapropel $\mathrm{S} 1$, as shown by the different $\mathrm{S} 1$ arrays that deviate from the modern EMS field (Figs. 2 and 6). Despite a general consensus that the Nile reached its peak discharge during sapropel S1, the mapping of surface-water $\delta^{18} \mathrm{O}$ anomalies recorded in planktonic foraminifera failed to identify the Nile as a single point-source (Kallel et al., 1997; Rohling and De Rijk, 1999; Emeis et al., 2000). Instead, a widely distributed depletion of $\delta^{18} \mathrm{O}$ is found throughout the Levantine Basin, causing a weakening of the west-east gradient (Rohling and De Rijk, 1999; Emeis et al., 2000). In addition to the Nile discharge, the weakened west-east salinity gradient during sapropel times may partly reflect an increase in circum-Mediterranean humidity and the consequently enhanced NBEM riverine inputs (e.g. Kallel et al., 1997; BarMatthews et al., 2000; Magny et al., 2013; Toucanne et al., 2015). In addition, these variations partly reflect monsoon-sourced runoff along the wider North-African margin into the central Mediterranean, at least during many, if not all, sapropels (e.g. Freydier et al., 2001; Rohling et al., 2002, 2004; Emeis et al., 2003; Larrasoaña et al., 2003; Sangiorgi et al., 2006; Osborne et al., 2008, 2010; Wu et al., 2016, 2017) (see Section 1.2 and the following discussion).

In summary, during the time of sapropel S5 deposition, the pronounced last interglacial insolation maximum led to a development of dense vegetation and extensive fluvial systems over the presently hyperarid Saharan Desert, resulting in a much diminished emission of Saharan dust and enhanced riverine inputs to all parts of the EMS (Cheddadi and Rossignol-Strick, 1995; Weldeab et al., 2002b; Larrasoaña et al., 2003; Castañeda et al., 2009; Liu et al., 2012). Therefore, the geochemical variability of the sapropel S5 detrital sediments is attributed predominantly to the amount and composition of detrital material delivered via rivers, and the subsequent distribution by currents.

\subsection{Characterization of major riverine supplies during sapropel S5}

For sapropel S5 detrital sediments, the $\mathrm{Sr}$ and Nd isotope, major element, and REE data reveal a strong east-west gradient and the influences of different riverine contributions: namely the Nile discharge, the NBEM (i.e. Aegean and Adriatic) riverine inputs, and the LibyanTunisian paleodrainage fluxes (Figs. 2-5).

\subsubsection{Nile discharge and Aegean riverine inputs}

The Nile sediment is mostly derived from the weathering products of Cenozoic basaltic rocks in the Ethiopian Highlands, thus characterized by relatively low ${ }^{87} \mathrm{Sr} /{ }^{86} \mathrm{Sr}$ and high $\varepsilon_{\mathrm{Nd}}$, high $\mathrm{Ti}$, low $\mathrm{K}$ and $\mathrm{Mg}$ contents, as well as high HREE and Eu concentrations (Krom et al., 


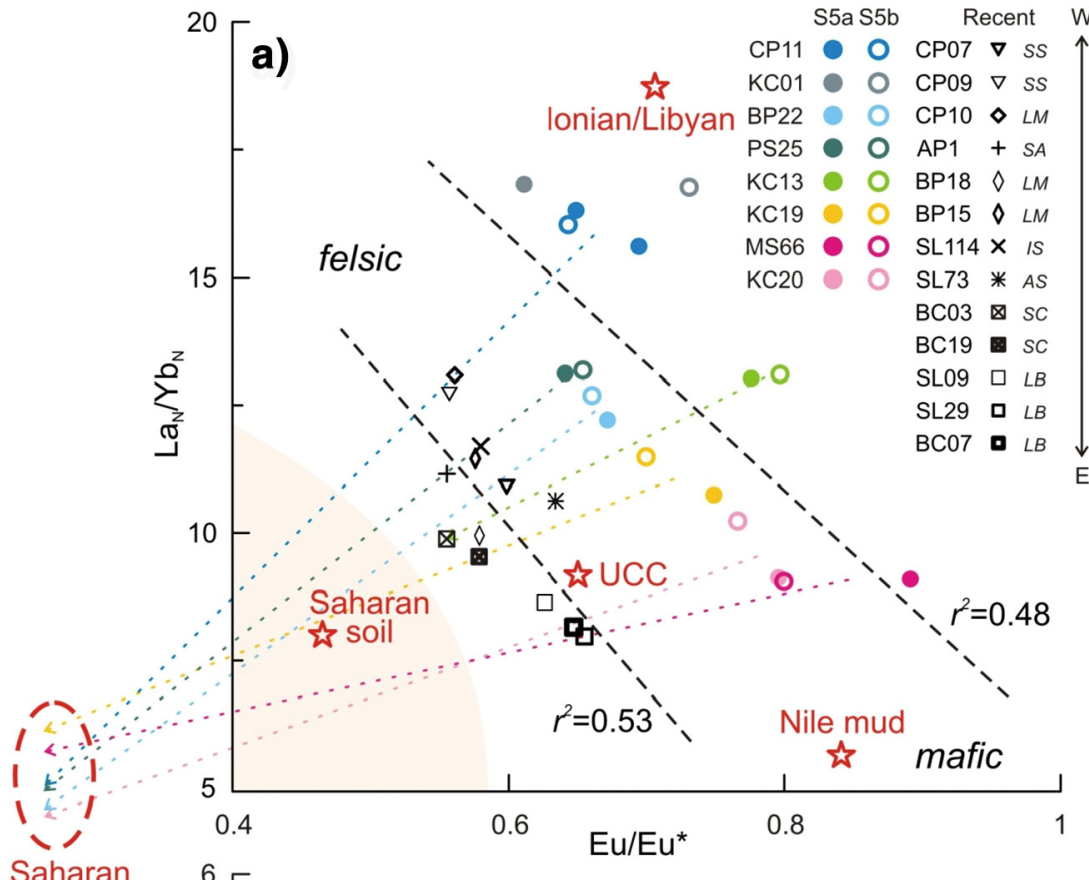
endmember

\section{b)}

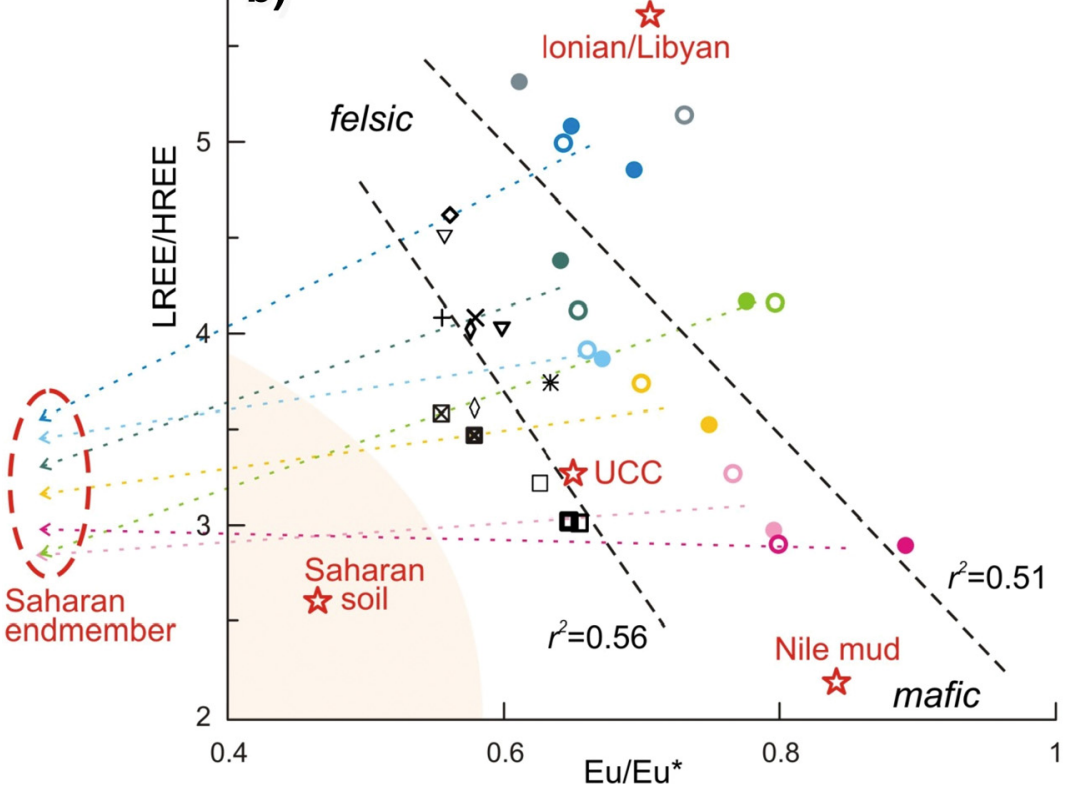

Fig. 5. Plots of a) $\mathrm{La}_{N} / \mathrm{Yb}_{\mathrm{N}}$ and b) LREE/HREE vs. Eu/Eu* for sapropel S5 and recent detrital sediments, respectively (Table 4). With normalization to chondrite (Boynton, 1985), the REE-derived parameters exhibit close negative correlations, indicating the relative contributions from felsic vs. mafic rock source areas. This is in good agreement with the Saharan soil and Nile mud (Moreno et al., 2006; Padoan et al., 2011). Sapropel S5 samples are differentiated between S5a and S5b (see Section 2). The distinct differences in the arrays between sapropel S5 and recent samples indicate the modern impact of Saharan dust. For each site/area, the colored lines go from S5 sediments through the corresponding recent sediments all point to one and the same signature of Sahara, representing the similar, averaged Saharan-dust endmember. Note that average composition of the S5 and recent sediments are taken. The Levantine Basin sediments are characterized by a relative mafic Nile signature, whereas the more felsic signature for the southwestern EMS sediments points to an Ionian/Libyan provenance, which is characterized by relatively high values for all these REE parameters. A best possible estimate for the Ionian/Libyan provenance is given. The signatures of average upper continental crust (UCC) are also shown (Taylor and McLennan, 1985). For the abbreviations of EMS localities see caption of Fig. 2. 1999a, 1999b; Revel et al., 2010; Box et al., 2011; Padoan et al., 2011). Such isotopic and elemental fingerprints are clearly seen in all of the Nile-influenced samples, regardless of the climatic conditions (S5: KL83, KC20, and MS66; surface: BC19, SL09, SL29, and BC07) (Figs. 2-5). These data indicate the control of Nile discharge to the Levantine Basin sediments, with an approximately similar offshore spread of Nile-derived particulates for the sapropel S5 period and the present-day, i.e. roughly limited to east of $26^{\circ} \mathrm{E}$. This inference appears to be also true for sapropels S1 and S3 (Almogi-Labin et al., 2009; Wu et al., 2016).

For the cores around the Island of Crete, the influence of Aegean riverine inputs appears to only occur during humid, sapropel periods. Similar to the Nile, the S5 samples of KC19, KC13, and PS25 display relatively high HREE and positive Eu anomalies, which indicates a mafic provenance for the REE bearing host minerals (Taylor and McLennan, 1985; Padoan et al., 2011); while this pattern is not observed for the recent samples (BC19, BC03, SL73, and SL114) (Fig. 4).
The mafic provenance is consistent with the isotopic signature for the river-borne surface sediments in the Aegean Sea, which are derived from basalts and ultramafic rocks (Fig. 2). Because of the similarity in basin lithology and the resultant REE and Sr-Nd isotope composition, however, the Nile and Aegean riverine supplies cannot be distinguished using these proxies alone (Weldeab et al., 2002a, 2002b; Ehrmann et al., 2007; Klaver et al., 2015; Wu et al., 2016).

The mixture of Nile and NBEM contributions can be unraveled, however, using elemental geochemistry. In addition to the aeolianorigin $\mathrm{Ti}$, high contents of Nile-derived $\mathrm{Ti}$ are also shown in the Levantine Basin. The NBEM is thought to be an important contributor of illite and chlorite to the Ionian sediments, mainly via the rivers flowing into the Adriatic (Po and Apennines rivers) and Aegean Sea (southeastern European and Turkish rivers) (Venkatarathnam and Ryan, 1971; Guerzoni et al., 1999; Goudeau et al., 2013). As detrital K and Mg are usually associated with the clay minerals illite and chlorite respectively, increased NBEM riverine inputs may be documented by 


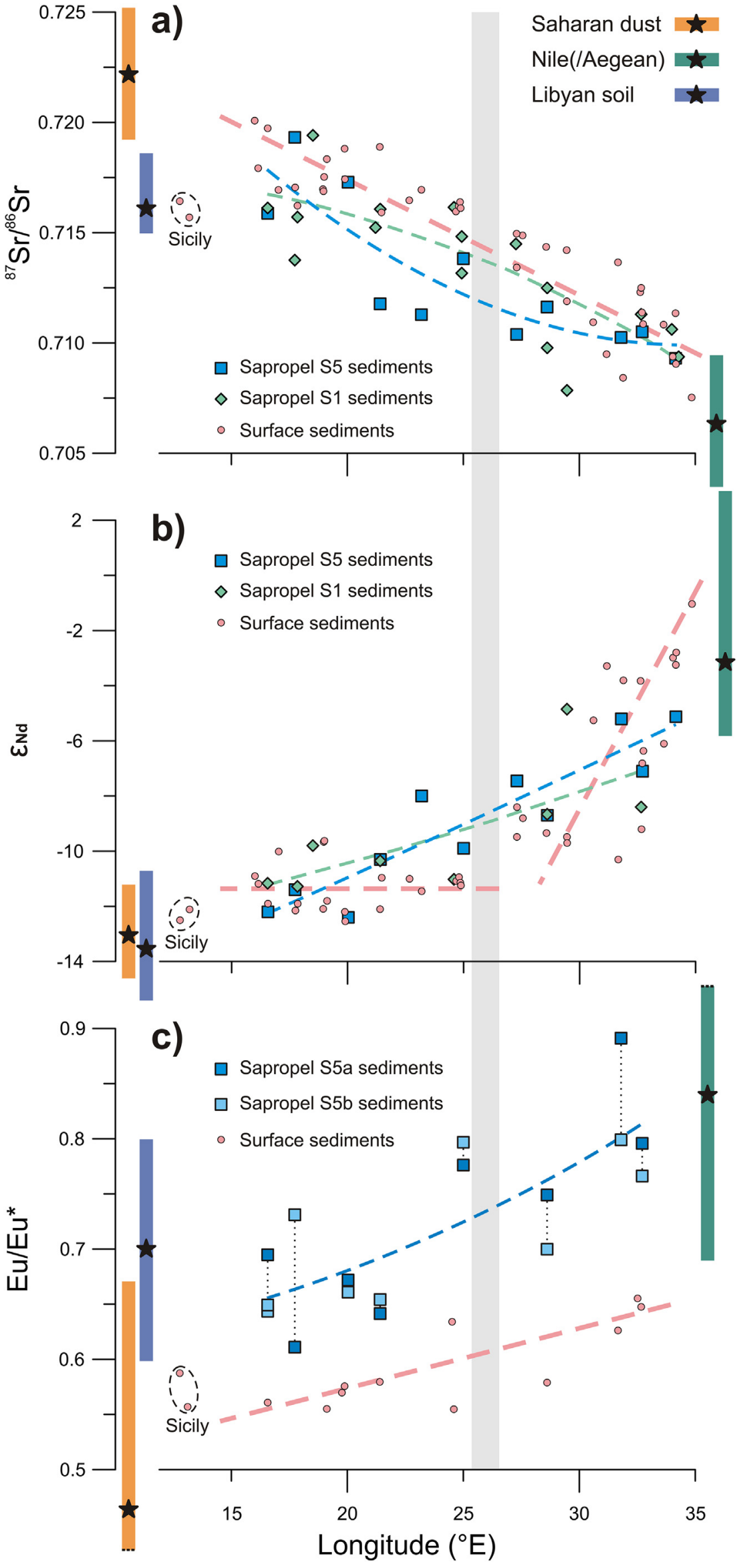

Fig. 6. Geochemical provenance proxies a) ${ }^{87} \mathrm{Sr} /{ }^{86} \mathrm{Sr}$, b) $\varepsilon_{\mathrm{Nd}}$, and c) $\mathrm{Eu} / \mathrm{Eu}^{*}$ versus longitude throughout the eastern Mediterranean Sea. The data for sapropel S5, S1, and surface detrital sediments distinctly indicate the relative riverine contributions during these different periods. Curves of nonlinear fit are shown for S5 and S1 data, while for surface sediments linear lines are used (excluding two data-points from the Strait of Sicily). The step-wise change in the recent $\varepsilon_{\mathrm{Nd}}$ data emphasizes that the Nile distribution is limited to the area south of Crete around $26^{\circ} \mathrm{E}$, as indicated by the vertical grey bar. The $\mathrm{Sr}$ and $\mathrm{Nd}$ isotopes data are compiled from previous studies (Frost et al., 1986; Krom et al., 1999b; Freydier et al., 2001; Weldeab et al., 2002a, 2002b; Tachikawa et al., 2004; Ehrmann et al., 2007; Revel et al. 2010, 2014; Box et al., 2011; Wu et al., 2016) and updated here (for details see Supplementary material). Anticipated endmembers and their ranges are given on the left and right. For $\mathrm{Sr}$ and $\mathrm{Nd}$ isotopes: after $\mathrm{Wu}$ et al. (2016). For $\mathrm{Eu} / \mathrm{Eu}^{*}$ : after Moreno et al. (2006) and Padoan et al. (2011) using Saharan desert soils and main Nile muds, respectively and it estimated from observations in Fig. 5 for Libyan soil. 
higher $\mathrm{K} / \mathrm{Al}$ and $\mathrm{Mg} / \mathrm{Al}$ in sapropel layers (e.g. Wehausen and Brumsack, 2000; Martinez-Ruiz et al., 2015, and references therein; Wu et al., 2016). In this context, it is clear that cores KC20 and MS66 are controlled by the Ti-rich Nile discharge, while the cores around Crete such as KC19, KC13, and PS25 are more influenced by the Mg-rich riverine inputs from the Aegean Sea (Fig. 3).

Furthermore, the relative distributions of the Nile and Aegean riverine supplies are revealed by the distinctly different trends in sapropel S5 samples (Fig. 3). Core KC19, located at the boundary between the Levantine Basin and south of Crete suggests that the Nile sediment contribution is confined to the areas east of $26^{\circ} \mathrm{E}$. This, again, indicates a limited offshore distribution of Nile sediment, even during sapropel S5. An alternative explanation is a stronger Aegean riverine input. This suggestion is consistent with previous studies concerning the Nile impact. The Sr and Nd isotope ratios on surface sediments have shown that the Nile sediment contribution rapidly decreases westward from the river-mouth to a limit south of Crete, around the Mediterranean Ridge (Krom et al., 1999a; Weldeab et al., 2002a). During sapropels, several lines of evidence argue strongly against a considerable Nile influence (i.e. dissolved and particulate) for the areas west of Crete (see in-depth discussion in Wu et al., 2016, 2017).

\subsubsection{Libyan-Tunisian paleodrainage and other riverine fluxes to the Ionian}

The similar mafic sources of the Nile- and Aegean -dominated areas concord with the relatively homogenous HREE distribution, whereas a more heterogeneous pattern of middle REE points to rather different felsic sources, i.e. a provenance from the areas around the Ionian Sea (Fig. 4). This is in line with the surface geology of river catchments over the EMS region. Specifically, the Ionian samples are characterized by strong LREE fractionation, a negative Eu anomaly, and a flat HREE pattern (Fig. 4), such as seen for the areas off Libya/Tunisia and the northern Ionian Sea (S5: KC01, CP11 and BP22; surface: AP1, CP07, CP09, CP10, BP15 and BP18). This indicates a felsic provenance. Moreover, it is clear that the REE data cannot be described by a simple mixing between Saharan dust and Nile sediment; at least one further component with a relatively high $\mathrm{Eu} / \mathrm{Eu}^{*}, \mathrm{La}_{\mathrm{N}} / \mathrm{Yb}_{\mathrm{N}}$, and LREE/HREE is required for the Ionian provenance (Fig. 5).

The Ionian Sea potentially receives detrital fluxes from the Aegean Sea, Adriatic Sea, Strait of Messina, Strait of Sicily, and also from Libya and Tunisia (Venkatarathnam and Ryan, 1971; Weldeab et al., 2002a) (Fig. 1). The surface samples over the Ionian area slightly deviate from the generally inverse relationship between $\mathrm{Sr}$ and $\mathrm{Nd}$ isotope ratios (Fig. 2). Specifically, the signatures of Adriatic and Messina have highest ${ }^{87} \mathrm{Sr} /{ }^{86} \mathrm{Sr}$ but not the lowest $\varepsilon_{\mathrm{Nd}}$ values (Weldeab et al., 2002a), whereas those of Sicily and Libya are characterized by the lowest $\varepsilon_{\mathrm{Nd}}$ and moderate ${ }^{87} \mathrm{Sr} /{ }^{86} \mathrm{Sr}$ ratio. The latter is revealed by our surface samples CP07 and BP15 collected from the Libyan-Tunisian margin, which expand on the existing EMS datasets (see Supplementary material). Accordingly, the Sr and Nd isotope ratios for cores CP11 and BP22 being lower than those for the surface samples from the same area (i.e. $\mathrm{CP} 07, \mathrm{CP} 10$, and $\mathrm{BP} 15)$ point to a significant Libyan riverine contribution during S5 time (Fig. 2).

Based on the compositions summarized in Fig. 3, the northwestern Ionian (core KC01) is mainly influenced by a K-rich Adriatic/Messina (NBEM) contribution, while for the southern Ionian (cores CP11 and BP22), there is an Mg-rich detrital contribution, especially for the S5b interval. Taken together, core KC01, close to the Gulf of Messina, appears to be mainly influenced by sediment outflows from the Strait of Messina and southern Adriatic Sea. By contrast, cores CP11 and BP22 are more controlled by detrital fluxes from the Libyan-Tunisian margin and Strait of Sicily.

These observations are in good agreement with previous studies (Freydier et al., 2001; Weldeab et al., 2002a; Wu et al., 2016, 2017). Riverine runoffs from the wider North-African margin have also been recorded for sapropel S5 time, using planktonic foraminiferal $\delta^{18} \mathrm{O}$ (Rohling et al., 2002, 2004) and Nd isotope ratios (Osborne et al., 2008,
2010). In addition, North-African runoff has been documented for sapropel S1 based on the Sr and Nd isotope ratios of the detrital component ( $\mathrm{Wu}$ et al., 2016). Aegean riverine inputs are composed of weathering products of ultramafic/mafic rocks, thus enriched in $\mathrm{Mg}$ (Wehausen and Brumsack, 2000; Klaver et al., 2015). In addition, a comprehensive comparison of detrital supplies between the Ionian cores has shown that the paleodrainage fluxes from the Libyan-Tunisian margin during sapropel S1 period are characterized by higher smectite and detrital $\mathrm{Mg} / \mathrm{Al}$ (Wu et al., 2017). This point is clear from Fig. 3, showing that for the Libyan-Tunisian margin, the sapropel S5 samples (CP11 and BP22) have systematically higher Mg contents for the surface sediments (CP07, CP09, CP10, BP15, and BP18).

\subsection{Basin-wide comparison of riverine contributions between different humid periods}

\subsubsection{Sapropel $S 5$ versus $S 1$}

Due to the extraordinary astronomical settings for the last interglacial insolation maximum, overall, sapropel S5 has far more runoff than the Holocene sapropel S1 (see Section 1.3). As discussed above, the Nile sediment contribution during sapropel S5 was not larger, or even slightly decreased, compared to that of sapropel S1 and the present-day. This inference is also clear from the Sr-Nd isotope data from the Levantine Basin; for a larger Nile contribution, the signatures of cores KL83, KC20, and MS66 should have a greater Nile-endmember composition, but this is not the case (Fig. 2). During sapropel S5 time, the African monsoon is anticipated to be more intensified than during S1. The higher summer precipitation may not have caused a higher Nile sediment supply, as the monsoon-generated vegetation cover is expected to be denser and consequently may have suppressed physical erosion and sediment removal from the Ethiopian highlands (e.g. Krom et al., 1999b; Weldeab et al., 2002b; Almogi-Labin et al., 2009; Box et al., 2011; Lézine et al., 2011; Hennekam et al., 2014). This interpretation is supported by the similar major-element signature for sapropel S5 (KC20 and MS66) and surface sediments (BC07, SL29, and SL09) in the Levantine Basin (Fig. 3), demonstrating that the Ti-rich detrital supply of the Nile did not increase significantly during sapropel S5 relative to the present.

By contrast, the influence of the Aegean riverine sediment input during sapropel S5 appears to have been much greater than during S1. This is indicated by the lower ${ }^{87} \mathrm{Sr} /{ }^{86} \mathrm{Sr}$ and higher $\varepsilon_{\mathrm{Nd}}$ ratios for the cores around Crete (KC19, SL67, KC13, SL71, and PS25), during sapropel S5 compared S1 (Fig. 2). This is in line with the increased seasonality of precipitation during the last interglacial maximum proposed to explain the apparent incongruity between various records (Cheddadi and Rossignol-Strick, 1995; Tzedakis, 2007; Milner et al., 2012). Indeed, the evidence of evaporative summer conditions based on pollen studies (e.g. Tzedakis et al., 2003; Allen and Huntley, 2009) coupled with increased winter precipitation recorded by speleothem and sapropel records (e.g. Bar-Matthews et al., 2000; Drysdale et al., 2005; Toucanne et al., 2015) indicates a strong precipitation seasonality over the NBEM during sapropel S5.

Enhanced NBEM riverine inputs during sapropel times are also consistent with the results from the major-element ternary diagram (Fig. 3). For the Aegean area, sapropel S5 samples (KC19, KC13, and PS25) are more towards the Mg-endmember than recent samples (BC19, BC03, SL73, and SL114). This trend is also observed for the Adriatic-related samples, showing that S5 sample of KC01 is more influenced by the K-rich Adriatic/Messina contribution than the AP1 surface sediment (Fig. 3a). Thus, all these data indicate enhanced riverine input from the NBEM, including the Aegean and Adriatic Sea. We note that our results contradict the finding of Osborne et al. (2010), who concluded that there was no large influx of Aegean riverine water during sapropel 55 using planktonic foraminiferal $\varepsilon_{\mathrm{Nd}}$. The explanation for these different interpretations is that the $\varepsilon_{\mathrm{Nd}}$ recorded in planktonic foraminifera is not related to the ambient seawater at calcification 
depth (i.e. surface water) but primarily reflects the bottom/pore water (Pomiés et al., 2002; Tachikawa et al., 2014).

Relative to the Libyan-Tunisian isotopic domain of sapropel S1, the S5-samples of cores CP11 and BP22 have consistently lower $\varepsilon_{\mathrm{Nd}}$ values, indicating stronger North-African paleodrainage fluxes during sapropel S5 than during S1 (Fig. 2). This is further corroborated by the majorelement data showing that sapropel S5 samples (CP11 and BP22) are higher in $\mathrm{Mg}$ than those for sapropel S1 (CP10/11, the same site as CP11) (Fig. 3). The fossil river/wadi networks over eastern Libya feed towards the Gulf of Sirte and have been considered the primary source of detritus for sapropel S5 deposition (e.g. Rohling et al., 2002, 2004; Osborne et al., 2008, 2010). This more eastern pathway deviates from the runoff pathway indicated for sapropel S1, which is in western Libya and Tunisia towards the Gulf of Gabès (Wu et al., 2016, 2017) (Fig. 1).

Compared to the most-humid phase of sapropel S1 (i.e. with the lowest ${ }^{87} \mathrm{Sr} /{ }^{86} \mathrm{Sr}$ and highest $\varepsilon_{\mathrm{Nd}}$ values in the Libyan-Tunisian domain) the relatively high ${ }^{87} \mathrm{Sr} /{ }^{86} \mathrm{Sr}$ ratios of $\mathrm{CP} 11$ and $\mathrm{BP} 22$ point to higher paleodrainage fluxes from the wider North-African margin (Fig. 2). Moreover, the recent sediments offshore eastern Libya (CP07, СР09, and $\mathrm{CP} 10$ ) have systematically higher Mg contents than those offshore western Libya/Tunisia (BP15 and BP18) (Fig. 3a). Thus, the derived paleodrainage fluxes with more enhanced $\mathrm{Mg} / \mathrm{Al}$ for S5 than for $\mathrm{S} 1$, point to a more eastern Libya provenance for these fluxes during sapropel S5 time. The riverine higher $\mathrm{Mg}$ is related to the weathering products of ultramafic/mafic rocks over the North-African paleodrainage areas (Wu et al., 2017).

In addition to the fluvial supplies from the south, shelf-derived initially river-borne material from the east (i.e. Strait of Sicily) is likely, as anticipated for sapropel S1 (Wu et al., 2016, 2017) (Fig. 2). Moreover, it seems that core KC01 is mainly controlled by the K-rich Adriatic/ Messina inputs, while it is much less influenced by the inferred supplies from the Libyan-Tunisian margin (Figs. 2 and 3). This core may mark a limit for the detectable distribution of North-African paleodrainagerelated detrital sediments during sapropel $\mathrm{S5}$.

\subsubsection{Sapropel $S 5 a$ versus $S 5 b$}

There are considerable differences between the two distinct periods: S5a and S5b (see Section 1.3). It has been suggested that the $\mathrm{X}$ value for S5a and S5b was reduced to respectively $5-45 \%$ and $35-60 \%$ of the present-day value (Rohling et al., 2004). From the perspective of detrital sediments, considering a much reduced and generally constant impact of Saharan dust during sapropel S5 (Cheddadi and RossignolStrick, 1995; Weldeab et al., 2002b; Larrasoaña et al., 2003; Castañeda et al., 2009; Liu et al., 2012), differences observed between S5a and S5b must be attributed to changes in riverine supplies.

It is clear that riverine detrital supplies from the southern EMS borderlands, North Africa, were more enhanced during S5b than S5a; whereas the opposite is observed for the northern borderlands (i.e. NBEM) (Fig. 3). Relative to S5a samples, S5b samples in cores KC20 and MS66 are more towards the Ti-rich Nile endmember (Fig. 3b), and more away from the Saharan dust endmember and from the Saharan dust dominated recent samples in cores of corresponding sites/area (SL09, SL29, and BC07) (Fig. 3a). Similarly, for cores CP11 and BP22, S5b samples are more towards the Mg-rich Libya/Tunisia endmember, and distant from the Saharan dust endmember and from the corresponding recent samples (CP10, BP15, and BP18), compared to S5a samples (Fig. 3). This pattern is in contrast to that for the NBEM. For the cores mainly influenced by Aegean riverine inputs (KC19, KC13, and PS25), compared to the S5b samples, S5a samples are closer to the Aegean river endmember, and more distant from the Saharan dust endmember and from the associated recent samples (BC19, BC03, and SL114) (Fig. 3). Likewise, the S5a sample of core KC01 appears to receive more K-rich Adriatic river-borne material than the S5b sample, as compared to the Adriatic and Saharan endmembers, and the recent AP1 sample (Fig. 3).

This south-north pattern is also generally observed in the REE data.
For the cores controlled by North-African provenance areas (KC20, MS66, KC19, BP22, and CP11), there are lower $\mathrm{Eu} / \mathrm{Eu}^{*}$, and higher $\mathrm{La}_{\mathrm{N}} /$ $\mathrm{Lu}_{\mathrm{N}}$ and LREE/HREE ratios, thus pointing to more enhanced runoff during S5b than S5a. The opposite is the case for the NBEM-influenced cores KC01, PS25, and KC13 (Fig. 5).

The higher NBEM riverine input during S5a is related to the increased seasonality of precipitation in the early part of the last interglacial maximum, coeval with boreal summer insolation maxima (Tzedakis, 2007; Milner et al., 2012) (see Section 4.3.1). Such climate effect is also evident for the analogous case of Holocene sapropel S1 (see review by Magny et al., 2013), where enhanced K-rich NBEM riverine contributions during the early phase of S1 (S1a) are associated with enhanced winter precipitation (e.g. Wu et al., 2017).

There are potentially different mechanisms for the monsoonsourced riverine supplies from North Africa. Although an enhanced Nile discharge should have had a major contribution to the excess basinwide freshwater input during S5a, as estimated from surface-water $\delta^{18} \mathrm{O}$ data (Rohling et al., 2004), a higher water flow did not necessarily result in a higher sediment supply. The Nile comprises two different systems: 1) the White Nile and 2) the Blue Nile and Atbara, affected by East African monsoon (Revel et al., 2010; Hennekam et al., 2014). At present, the latter provides $>50 \%$ of the water flow and $>95 \%$ of the sediment load, as the Sudd swamps in Sudan filter out most of the White Nile's suspension load (Foucault and Stanley, 1989; Padoan et al., 2011). Consequently, increased vegetation cover on the Ethiopian highlands - the source areas of the Blue Nile and Atbara, may have restricted the Nile sediment contribution (Krom et al., 1999b; Weldeab et al., 2002b; Box et al., 2011; Hennekam et al., 2014). In this context, the stronger Nile signatures during S5b than S5a could be related to the deterioration of the vegetation cover on the Ethiopian highlands.

The potential fluvial contributions from the wider North-African margin have been linked to the reactivation and delivery of paleodrainage systems derived from central Saharan mountains (Rohling et al., 2002, 2004; Osborne et al., 2008, 2010; Wu et al., 2016, 2017). It has recently been suggested that such paleodrainage fluxes were controlled by the Saharan humid surface, i.e. the area of interlinked fluvial systems, modulated by groundwater level, in response to the insolationdriven West African monsoon precipitation (see in-depth discussion in Wu et al., 2017). Specifically, the paleodrainage systems and associated networks were only fully developed, when the persistently high precipitation had replenished the groundwater to a sufficient level during the late part of S1 (S1b) (Lézine et al., 2011). It is therefore inferred that the resulting runoff developed to the greatest extent during the S1b interval (Wu et al., 2017). This scenario is thought to have occurred also for sapropel S5, with the highest paleodrainage fluxes during the S5b interval.

This is distinct from the Nile discharge that is controlled by East African monsoon precipitation and associated vegetation cover on the Ethiopian highlands. These differences may partly account for the different responses between the Libyan-Tunisian and Nile riverine contributions to the same insolation forcing.

\subsection{Integrating and quantifying detrital contributions for the eastern Mediterranean during sapropel S5}

To summarize, the isotopic and elemental composition of EMS detrital sediments reveals three main provenance areas, and a general west-east gradient (Fig. 6). Based on $\mathrm{Sr}$ and $\mathrm{Nd}$ isotopes, an overall stronger riverine contribution occurred during sapropel S5 than during $\mathrm{S} 1$, as reflected by the generally higher (lower) ${ }^{87} \mathrm{Sr} /{ }^{86} \mathrm{Sr}\left(\varepsilon_{\mathrm{Nd}}\right)$ ratios in the west, and the lower (higher) ${ }^{87} \mathrm{Sr} /{ }^{86} \mathrm{Sr}\left(\varepsilon_{\mathrm{Nd}}\right)$ ratios in the eastern section of the EMS (Fig. 6a,b). The Eu/Eu* ratios record the impact of Saharan dust that is much more enhanced in surface samples than sapropel S5 sediments (Fig. 6c).

Considering the complex provenance pattern and the inadequate information for the source endmembers, a quantitative calculation for 
the whole EMS basin is difficult. Despite that, semi-quantitative estimates can be made for the major provenance areas, based on qualified assumptions regarding the distribution of detrital supplies during sapropel periods, as shown in Fig. $2 \mathrm{~b}$ (for details see Supplementary material).

For the Levantine Basin, the mixing hyperbola constructed from $\mathrm{Sr}$ and $\mathrm{Nd}$ isotopes and concentrations of the complete Nile-delta sediments (Revel et al., 2010) is adopted to estimate the Nile vs. Saharan contributions (see Supplementary material). The Nile accounts for $\sim 65 \%$ and $\sim 55 \%$ of the detrital materials in cores MS66 and KC20 during sapropel S5 (Fig. 2), in good agreement with the Blue Nile contribution ranging between 40 and $70 \%$ for humid sapropel periods (Revel et al., 2010). For the present-day, a Nile contribution of $60-80 \%$ and $40-60 \%$ is reported for the sites of MS66 and KC20, respectively, as estimated from surface sediment Sr isotopes (Krom et al., 1999a).

For the western parts of the EMS, at least a ternary mixing system is required. For the areas around Crete, where the Nile contribution was largely reduced, a rough estimate can be made from the major-element ternary diagram using the Saharan, Aegean/Nile, and Libyan endmembers (Fig. 3; see Supplementary material). The estimated detrital contributions for the cores between $\sim 25$ and $30^{\circ} \mathrm{E}$ are as follows (KC19; KC13): Nile $(\sim 10 \%$; <5\%), Aegean $(50-60 \% ; 30-40 \%)$, Libyan ( $<5 \%$; 40-50\%), and Saharan ( $25 \%$; 20\%). Note that KC19 appears to mark a distribution limit of the Libyan-Tunisian paleodrainage fluxes, and has a similar Nile contribution as presently ( $\sim-10 \%)$; while KC13 has a negligible Nile influence even during sapropel times (Fig. 2b; also see Section 4.2).

It is clear that enhanced NBEM riverine inputs dominate the northern Ionian Sea during sapropel S5 (i.e. PS25 and KC01), but the Adriatic and Aegean contributions cannot be clearly differentiated (Fig. 2b). Moreover, this area may be affected by the detrital supplies from Sicily and Messina, which makes the provenance even more complex. It appears, however, that the inferred Libyan-Tunisian paleodrainage systems contributed only a small amount of detrital materials to core KC01, but considerably more to PS25 (Figs. 2 and 3).

In general, the paleodrainage contribution from the Libyan-Tunisian margin must have been larger during sapropel S5 than during S1 (Figs. 2 and 3). The S1 paleodrainage fluxes account for $40-70 \%$ of the detrital sediment variability in core $\mathrm{CP} 10 / 11$, as calculated from a multiproxy approach (Wu et al., 2017). This is also supported by the Sr$\mathrm{Nd}$ isotope data of sapropel S1 samples in core CP10 ( 60\%) (Wu et al., 2016); applying a similar approach for S5 samples of CP11 and BP22, this gives a paleodrainage-related contribution of $60-75 \%$. Consequently, despite variable detrital components from riverine NBEM, Sicily shelf-derived materials, and Saharan dust, the predominant contribution to the southern Ionian Sea is from reactivated Libyan paleodrainage fluxes.

\section{Conclusions}

Based on a basin-wide geochemical characterization of Eastern Mediterranean sediments, we evaluate the riverine supplies at the times of sapropel S5 deposition and make comparisons with the present-day and the Holocene sapropel S1 period. The following conclusions are drawn:

a) During the humid-phase MIS 5e, coinciding with sapropel S5 deposition, there was minor Saharan dust over the EMS. Therefore the geochemical variability of sapropel S5 detrital sediments is mostly due to a mixing between three riverine contributions: Nile discharge, Northern Borderlands of Eastern Mediterranean (i.e. NBEM) riverine inputs, and Libyan-Tunisian paleodrainage fluxes.

b) The intensified African monsoon during MIS 5e and the associated denser vegetation cover has resulted in reduced erosion for the Blue Nile catchment areas. Consequently, despite substantially enhanced runoff, the offshore spatial distribution of Nile sediments during sapropel S5 was not larger than during sapropel S1 or today. The Nile sediment contribution is only dominant for the Levantine Basin, decreasing to undetectable levels south of Crete in sapropel S5, S1, and recent sediments.

c) An increase in the Aegean riverine inputs is observed around Crete in sapropel S5 time. This enhanced distribution is associated with the strong precipitation seasonality over the NBEM, especially for the early part of the last interglacial maximum (i.e. S5a).

d) Considerable fluvial contributions from the wider North-African margin are found in Ionian Sea sediments. Such sediment supplies must be transported via the paleodrainage systems derived from central Saharan mountains, which were reactivated by intensified monsoon precipitation. These sediment supplies were more prominent for the S5b than for the S5a phase. Moreover, the paleodrainage fluxes during sapropel S5 were stronger and appear to be preferentially derived from eastern Libya, in contrast to those during sapropel S1 which were mainly derived from western Libya/Tunisia.

Our approach demonstrates the effectiveness of a combination of major elements, REE, and Sr-Nd isotopes in determining provenance. In particular, the elemental fingerprints of detrital sediment have shown to be very practical and have a great potential for EMS provenance studies, not only due to their ease-of-analysis compared to isotope data, but also supplying essential complementary information.

\section{Acknowledgements}

We thank the captain \& crew, scientists, and technicians on board the cruises of MD69-MARFLUX 1991, MD81-PALEOFLUX 1995 with RV Marion Dufresne, SIN-SAP 1998 with RV Urania, SMILABLE 1999 with RV Logachev, as well as of PASAP 2000, BIOPASS 2001, PALEOPASS \& MIMES 2004, and CORTADO 2011 with RV Pelagia, for their contributions to sample collection. Financial support from EU-projects MARFLUX (MAST1-90022C), PALEOFLUX (MAS2-CT93-0051) \& SAP (MAS3-CT97-0137), and from CNR and NWO for shiptime and logistics are acknowledged. We are grateful to Coen Mulder and Helen de Waard for ICP-OES and -MS analyses at Utrecht University. Many thanks are given to Richard J. Smeets who helped with chromatography, to Alice Knaf, Mathijs van de Ven, and Bas van der Wagt for Sr and Nd isotope measurements at VU Amsterdam. We appreciate the constructive comments from two anonymous reviewers that have improved the final manuscript, and the editorial handling of Michael Böttcher. This study is part of JW's PhD project, funded by the China Scholarship Council Utrecht University PhD Program (CSC No. 201206260116; USES contribution No. 146).

\section{Appendix A. Supplementary data}

Supplementary data to this article can be found online at https:// doi.org/10.1016/j.chemgeo.2018.03.037.

\section{References}

Allen, J.R.M., Huntley, B., 2009. Last interglacial palaeovegetation, palaeoenvironments and chronology: a new record from Lago Grande di Monticchio, southern Italy. Quat. Sci. Rev. 28, 1521-1538.

Almogi-Labin, A., Bar-Matthews, M., Shriki, D., Kolosovsky, E., Paterne, M., Schilman, B., Ayalon, A., Aizenshtat, Z., Matthews, A., 2009. Climatic variability during the last similar to $90 \mathrm{ka}$ of the southern and northern Levantine Basin as evident from marine records and speleothems. Quat. Sci. Rev. 28, 2882-2896.

Bar-Matthews, M., Ayalon, A., Kaufman, A., 2000. Timing and hydrological conditions of Sapropel events in the eastern Mediterranean, as evident from speleothems, Soreq cave, Israel. Chem. Geol. 169, 145-156.

Berger, A., Loutre, M.F., 1991. Insolation values for the climate of the last 10 million years. Quat. Sci. Rev. 10, 297-317.

Bianchi, D., Zavatarelli, M., Pinardi, N., Capozzi, R., Capotondi, L., Corselli, C., Masina, S., 2006. Simulations of ecosystem response during the sapropel S1 deposition event. Palaeogeogr. Palaeoclimatol. Palaeoecol. 235, 265-287.

Boere, A.C., Rijpstra, W.I.C., de Lange, G.J., Malinverno, E., Damste, J.S.S., Coolen, 
M.J.L., 2011. Exploring preserved fossil dinoflagellate and haptophyte DNA signatures to infer ecological and environmental changes during deposition of sapropel S1 in the eastern Mediterranean. Paleoceanography 26, PA2204. http://dx.doi.org/ 10.1029/2010PA001948.

Bout-Roumazeilles, V., Nebout, N.C., Peyron, O., Cortijo, E., Landais, A., MassonDelmotte, V., 2007. Connection between South Mediterranean climate and North African atmospheric circulation during the last 50,000 yr BP North Atlantic cold events. Quat. Sci. Rev. 26, 3197-3215.

Box, M.R., Krom, M.D., Cliff, R.A., Bar-Matthews, M., Almogi-Labin, A., Ayalon, A., Paterne, M., 2011. Response of the Nile and its catchment to millennial-scale climatic change since the LGM from Sr isotopes and major elements of East Mediterranean sediments. Quat. Sci. Rev. 30, 431-442.

Boynton, W.V., 1985. Cosmochemistry of the rare earth elements: Meteorite studies. In: Henderson, P. (Ed.), Rare Earth Element Geochemistry. Elsevier, Amsterdam, pp. 115-1522.

Castañeda, I.S., Mulitza, S., Schefuss, E., dos Santos, R.A.L., Damste, J.S.S., Schouten, S 2009. Wet phases in the Sahara/Sahel region and human migration patterns in North Africa. Proc. Natl. Acad. Sci. U. S. A. 106, 20159-20163.

Cheddadi, R., Rossignol-Strick, M., 1995. Eastern Mediterranean quaternary paleoclimates from pollen and isotope records of marine cores in the Nile cone area. Paleoceanography 10, 291-300.

Colin, C., Turpin, L., Blamart, D., Frank, N., Kissel, C., Duchamp, S., 2006. Evolution of weathering patterns in the Indo-Burman Ranges over the last 280 kyr: Effects of sediment provenance on $87 \mathrm{Sr} / 86 \mathrm{Sr}$ ratios tracer. Geochem. Geophys. Geosyst. 7 , Q03007. http://dx.doi.org/10.1029/2005GC000962.

Coulthard, T.J., Ramirez, J.A., Barton, N., Rogerson, M., Brücher, T., 2013. Were rivers flowing across the Sahara during the Last Interglacial? Implications for human migration through Africa. PLoS One 8, e74834. http://dx.doi.org/10.1371/journal. pone.0074834.

Dang, H.W., Jian, Z.M., Kissel, C., Bassinot, F., 2015. Precessional changes in the western equatorial Pacific hydroclimate: A 240 kyr marine record from the Halmahera Sea, East Indonesia. Geochem. Geophys. Geosyst. 16, 148-164.

De Lange, G.J., Ten Haven, H.L., 1983. Recent sapropel formation in the Eastern Mediterranean. Nature 305, 797-798.

De Lange, G.J., Thomson, J., Reitz, A., Slomp, C.P., Principato, M.S., Erba, E., Corselli, C., 2008. Synchronous basin-wide formation and redox-controlled preservation of a Mediterranean sapropel. Nat. Geosci. 1, 606-610.

Dolenec, T., Faganeli, J., Pirc, S., 1998. Major, minor and trace elements in surficia sediments from the open Adriatic Sea: a regional geochemical study. Geologia Croatica 51, 59-73.

Drake, N.A., Blench, R.M., Armitage, S.J., Bristow, C.S., White, K.H., 2011. Ancient watercourses and biogeography of the Sahara explain the peopling of the desert. Proc Natl. Acad. Sci. U. S. A. 108, 458-462.

Drysdale, R.N., Zanchetta, G., Hellstrom, J.C., Fallick, A.E., Zhao, J.X., 2005. Stalagmite evidence for the onset of the Last Interglacial in southern Europe at $129 \pm 1 \mathrm{ka}$. Geophys. Res. Lett. 32, L24708. http://dx.doi.org/10.1029/2005GL024658.

Ehrmann, W., Schmiedl, G., Hamann, Y., Kuhnt, T., Hemleben, C., Siebel, W., 2007. Clay minerals in late glacial and Holocene sediments of the northern and southern Aegean Sea. Palaeogeogr. Palaeoclimatol. Palaeoecol. 249, 36-57.

Emeis, K.C., Struck, U., Schulz, H.M., Rosenberg, R., Bernasconi, S., Erlenkeuser, H., Sakamoto, T., Martinez-Ruiz, F., 2000. Temperature and salinity variations of Mediterranean Sea surface waters over the last 16,000 years from records of planktonic stable oxygen isotopes and alkenone unsaturation ratios. Palaeogeogr. Palaeoclimatol. Palaeoecol. 158, 259-280.

Emeis, K.C., Schulz, H., Struck, U., Rossignol-Strick, M., Erlenkeuser, H., Howell, M.W. Kroon, D., Mackensen, A., Ishizuka, S., Oba, T., Sakamoto, T., Koizumi, I., 2003. Eastern Mediterranean surface water temperatures and $\delta^{18} \mathrm{O}$ composition during deposition of sapropels in the late Quaternary. Paleoceanography 18, 1005. http:// dx.doi.org/10.1029/2000PA000617.

Filippidi, A., Triantaphyllou, M.V., De Lange, G.J., 2016. Eastern-Mediterranean ventilation variability during sapropel S1 formation, evaluated at two sites influenced by deep-water formation from Adriatic and Aegean Seas. Quat. Sci. Rev. 144, 95-106.

Foucault, A., Stanley, D.J., 1989. Late Quaternary paleoclimatic oscillations in East Africa recorded by heavy minerals in the Nile delta. Nature 339, 44-46.

Freydier, R., Michard, A., de Lange, G.J., Thomson, J., 2001. Nd isotopic compositions of Eastern Mediterranean sediments: tracers of the Nile influence during sapropel S1 formation? Mar. Geol. 177, 45-62.

Frost, C., O'Nions, R., Goldstein, S., 1986. Mass balance for Nd in the Mediterranean Sea. Chem. Geol. 55, 45-50.

Goudeau, M.L.S., Grauel, A.L., Bernasconi, S.M., de Lange, G.J., 2013. Provenance of surface sediments along the southeastern Adriatic coast off Italy: an overview. Estuar. Coast. Shelf Sci. 134, 45-56.

Govindaraju, K., 1994. 1994 compilation of working values and sample description for 383 geostandards. Geostand. Geoanal. Res. 18, 1-158.

Grelaud, M., Marino, G., Ziveri, P., Rohling, E.J., 2012. Abrupt shoaling of the nutricline in response to massive freshwater flooding at the onset of the last interglacial sapropel event. Paleoceanography 27, PA3208. http://dx.doi.org/10.1029/ 2012PA002288.

Grimm, R., Maier-Reimer, E., Mikolajewicz, U., Schmiedl, G., Muller-Navarra, K., Adloff, F., Grant, K.M., Ziegler, M., Lourens, L.J., Emeis, K.C., 2015. Late glacial initiation of Holocene eastern Mediterranean sapropel formation. Nat. Commun. 6, 7099. http:// dx.doi.org/10.1038/ncomms8099.

Griselin, M., van Belle, J.C., Pomies, C., Vroon, P.Z., van Soest, M.C., Davies, G.R., 2001 An improved chromatographic separation technique of $\mathrm{Nd}$ with application to $\mathrm{NdO}^{+}$ isotope analysis. Chem. Geol. 172, 347-359.

Guerzoni, S., Chester, R., Dulac, F., Herut, B., Loye-Pilot, M.D., Measures, C., Migon, C.,
Molinaroli, E., Moulin, C., Rossini, P., Saydam, C., Soudine, A., Ziveri, P., 1999. The role of atmospheric deposition in the biogeochemistry of the Mediterranean Sea. Prog. Oceanogr. 44, 147-190.

Hennekam, R., Jilbert, T., Schnetger, B., de Lange, G.J., 2014. Solar forcing of Nile discharge and sapropel S1 formation in the early to middle Holocene eastern Mediterranean. Paleoceanography 29, 343-356.

Hoffmann, D.L., Rogerson, M., Spotl, C., Luetscher, M., Vance, D., Osborne, A.H., Fello, N.M., Moseley, G.E., 2016. Timing and causes of North African wet phases during the last glacial period and implications for modern human migration. Sci. Rep. 6, 36367. http://dx.doi.org/10.1038/srep36367.

Jacobsen, S.B., Wasserburg, G.J., 1980. Sm-Nd isotopic evolution of chondrites. Earth Planet. Sci. Lett. 50, 139-155.

Kallel, N., Paterne, M., Duplessy, J.C., VergnaudGrazzini, C., Pujol, C., Labeyrie, L. Arnold, M., Fontugne, M., Pierre, C., 1997. Enhanced rainfall in the Mediterranean region during the last sapropel event. Oceanol. Acta 20, 697-712.

Klaver, M., Djuly, T., de Graaf, S., Sakes, A., Wijbrans, J., Davies, G., Vroon, P., 2015 Temporal and spatial variations in provenance of Eastern Mediterranean Sea sediments: Implications for Aegean and Aeolian arc volcanism. Geochim. Cosmochim. Acta 153, 149-168.

Kraal, P., Slomp, C.P., de Lange, G.J., 2010. Sedimentary organic carbon to phosphorus ratios as a redox proxy in Quaternary records from the Mediterranean. Chem. Geol. 277, 167-177.

Krom, M.D., Cliff, R.A., Eijsink, L.M., Herut, B., Chester, R., 1999a. The characterisation of Saharan dusts and Nile particulate matter in surface sediments from the Levantine basin using Sr isotopes. Mar. Geol. 155, 319-330.

Krom, M.D., Michard, A., Cliff, R.A., Strohle, K., 1999b. Sources of sediment to the Ionian Sea and western Levantine basin of the eastern Mediterranean during S-1 sapropel times. Mar. Geol. 160, 45-61.

Kukla, G., McManus, J.F., Rousseau, D.D., Chuine, I., 1997. How long and how stable was the last interglacial? Quat. Sci. Rev. 16, 605-612.

Larrasoaña, J.C., Roberts, A.P., Rohling, E.J., Winklhofer, M., Wehausen, R., 2003. Three million years of monsoon variability over the northern Sahara. Clim. Dyn. 21 689-698.

Lézine, A.M., Hely, C., Grenier, C., Braconnot, P., Krinner, G., 2011. Sahara and Sahel vulnerability to climate changes, lessons from Holocene hydrological data. Quat. Sci. Rev. 30, 3001-3012.

Liu, Q.S., Larrasoana, J.C., Torrent, J., Roberts, A.P., Rohling, E.J., Liu, Z.F., Jiang, Z.X., 2012. New constraints on climate forcing and variability in the circumMediterranean region from magnetic and geochemical observations of sapropels S1, S5 and S6. Palaeogeogr. Palaeoclimatol. Palaeoecol. 333, 1-12.

Lourens, L.J., 2004. Revised tuning of Ocean Drilling Program Site 964 and KC01B (Mediterranean) and implications for the delta O-18, tephra, calcareous nannofossil, and geomagnetic reversal chronologies of the past 1.1 Myr. Paleoceanography 19, PA3010. http://dx.doi.org/10.1029/2003PA000997.

Lourens, L.J., Wehausen, R., Brumsack, H.J., 2001. Geological constraints on tidal dissipation and dynamical ellipticity of the Earth over the past three million years. Nature 409, 1029-1033.

Magny, M., Combourieu-Nebout, N., de Beaulieu, J.L., Bout-Roumazeilles, V., Colombaroli, D., Desprat, S., Francke, A., Joannin, S., Ortu, E., Peyron, O., Revel, M., Sadori, L., Siani, G., Sicre, M.A., Samartin, S., Simonneau, A., Tinner, W., Vanniere, B., Wagner, B., Zanchetta, G., Anselmetti, F., Brugiapaglia, E., Chapron, E., Debret, M., Desmet, M., Didier, J., Essallami, L., Galop, D., Gilli, A., Haas, J.N., Kallel, N. Millet, L., Stock, A., Turon, J.L., Wirth, S., 2013. North-south palaeohydrological contrasts in the central Mediterranean during the Holocene: tentative synthesis and working hypotheses. Clim. Past 9, 2043-2071.

Marino, G., Rohling, E.J., Rijpstra, W.I.C., Sangiorgi, F., Schouten, S., Damste, J.S.S., 2007. Aegean Sea as driver of hydrographic and ecological changes in the eastern Mediterranean. Geology 35, 675-678.

Martinez-Ruiz, F., Kastner, M., Gallego-Torres, D., Rodrigo-Gamiz, M., Nieto-Moreno, V., Ortega-Huertas, M., 2015. Paleoclimate and paleoceanography over the past $20,000 \mathrm{yr}$ in the Mediterranean Sea Basins as indicated by sediment elemental proxies. Quat. Sci. Rev. 107, 25-46.

Meyer, I., Davies, G.R., Stuut, J.B.W., 2011. Grain size control on Sr-Nd isotope provenance studies and impact on paleoclimate reconstructions: An example from deep-sea sediments offshore NW Africa. Geochem. Geophys. Geosyst. 12, Q03005. http://dx. doi.org $/ 10.1029 / 2010$ GC003355.

Milner, A.M., Collier, R.E.L., Roucoux, K.H., Muller, U.C., Pross, J., Kalaitzidis, S. Christanis, K., Tzedakis, P.C., 2012. Enhanced seasonality of precipitation in the Mediterranean during the early part of the Last Interglacial. Geology 40, 919-922.

Moreno, T., Querol, X., Castillo, S., Alastuey, A., Cuevas, E., Herrmann, L., Mounkaila, M., Elvira, J., Gibbons, W., 2006. Geochemical variations in aeolian mineral particles from the Sahara-Sahel Dust Corridor. Chemosphere 65, 261-270.

Myers, P.G., 2002. Flux-forced simulations of the paleocirculation of the Mediterranean Paleoceanography 17, 1009. http://dx.doi.org/10.1029/2000PA000613.

Myers, P.G., Haines, K., Rohling, E.J., 1998. Modeling the paleocirculation of the Mediterranean: the last glacial maximum and the Holocene with emphasis on the formation of sapropel S-1. Paleoceanography 13, 586-606.

Nesbitt, H.W., 1979. Mobility and fractionation of REE during weathering of a granodiorite. Nature 279, 206-210.

Osborne, A.H., Vance, D., Rohling, E.J., Barton, N., Rogerson, M., Fello, N., 2008. A humid corridor across the Sahara for the migration of early modern humans out of Africa 120,000 years ago. Proc. Natl. Acad. Sci. U. S. A. 105, 16444-16447.

Osborne, A.H., Marino, G., Vance, D., Rohling, E.J., 2010. Eastern Mediterranean surface water Nd during Eemian sapropel S5: monitoring northerly (mid-latitude) versus southerly (sub-tropical) freshwater contributions. Quat. Sci. Rev. 29, 2473-2483.

Padoan, M., Garzanti, E., Harlavan, Y., Villa, I.M., 2011. Tracing Nile sediment sources by 
Sr and Nd isotope signatures (Uganda, Ethiopia, Sudan). Geochim. Cosmochim. Acta $75,3627-3644$.

Paillou, P., Schuster, M., Tooth, S., Farr, T., Rosenqvist, A., Lopez, S., Malezieux, J.M., 2009. Mapping of a major paleodrainage system in eastern Libya using orbital imaging radar: The Kufrah River. Earth Planet. Sci. Lett. 277, 327-333.

Paillou, P., Tooth, S., Lopez, S., 2012. The Kufrah paleodrainage system in Libya: A past connection to the Mediterranean Sea? Compt. Rendus Geosci. 344, 406-414.

Passier, H.F., Dekkers, M.J., de Lange, G.J., 1998. Sediment chemistry and magnetic properties in an anomalously reducing core from the eastern Mediterranean Sea. Chem. Geol. 152, 287-306.

Pinardi, N., Masetti, E., 2000. Variability of the large scale general circulation of the Mediterranean Sea from observations and modelling: a review. Palaeogeogr. Palaeoclimatol. Palaeoecol. 158, 153-174.

Pomiés, C., Davies, G.R., Connan, S., 2002. Nd systematics of modern Indian Ocean Foraminifera: implications for the use of Nd isotopes in palaeoceanography. Earth Planet. Sci. Lett. 203, 1031-1045.

Reitz, A., Thomson, J., de Lange, G.J., Hensen, C., 2006. Source and development of large manganese enrichments above eastern Mediterranean sapropel S1. Paleoceanography 21, 4. http://dx.doi.org/10.1029/2005PA001169.

Revel, M., Ducassou, E., Grousset, F.E., Bernasconi, S.M., Migeon, S., Revillon, S., Mascle, J., Murat, A., Zaragosi, S., Bosch, D., 2010. 100,000 Years of African monsoon variability recorded in sediments of the Nile margin. Quat. Sci. Rev. 29, 1342-1362.

Revel, M., Colin, C., Bernasconi, S., Combourieu-Nebout, N., Ducassou, E., Grousset, F.E., Rolland, Y., Migeon, S., Bosch, D., Brunet, P., Zhao, Y.L., Mascle, J., 2014. 21,000 Years of Ethiopian African monsoon variability recorded in sediments of the western Nile deep-sea fan. Reg. Environ. Chang. 14, 1685-1696.

Révillon, S., Jouet, G., Bayon, G., Rabineau, M., Dennielou, B., Hemond, C., Berne, S. 2011. The provenance of sediments in the Gulf of Lions, western Mediterranean Sea. Geochem. Geophys. Geosyst. 12, Q08006. http://dx.doi.org/10.1029/ 2011GC003523.

Rodrigo-Gámiz, M., Martinez-Ruiz, F., Chiaradia, M., Jimenez-Espejo, F.J., Ariztegui, D., 2015. Radiogenic isotopes for deciphering terrigenous input provenance in the western Mediterranean. Chem. Geol. 410, 237-250.

Rohling, E.J., 1994. Review and new aspects concerning the formation of Eastern Mediterranean sapropels. Mar. Geol. 122, 1-28.

Rohling, E.J., 1999. Environmental control on Mediterranean salinity and $\delta^{18} \mathrm{O}$. Paleoceanography 14, 706-715.

Rohling, E.J., De Rijk, S., 1999. Holocene climate optimum and last glacial maximum in the Mediterranean: the marine oxygen isotope record. Mar. Geol. (161), 385-387.

Rohling, E.J., Cane, T.R., Cooke, S., Sprovieri, M., Bouloubassi, I., Emeis, K.C., Schiebel, R., Kroon, D., Jorissen, F.J., Lorre, A., Kemp, A.E.S., 2002. African monsoon variability during the previous interglacial maximum. Earth Planet. Sci. Lett. 202, 61-75.

Rohling, E.J., Sprovieri, M., Cane, T., Casford, J.S.L., Cooke, S., Bouloubassi, I., Emeis, K.C., Schiebel, R., Rogerson, M., Hayes, A., Jorissen, F.J., Kroon, D., 2004. Reconstructing past planktic foraminiferal habitats using stable isotope data: a case history for Mediterranean sapropel S5. Mar. Micropaleontol. 50, 89-123.

Rohling, E.J., Marino, G., Grant, K.M., 2015. Mediterranean climate and oceanography, and the periodic development of anoxic events (sapropels). Earth Sci. Rev. 143, 62-97.

Rossignol-Strick, M., 1983. African monsoons, an immediate climate response to orbital insolation. Nature 304, 46-49.

Rutten, A., de Lange, G.J., Ziveri, P., Thomson, J., van Santvoort, P.J.M., Colley, S., Corselli, C., 2000. Recent terrestrial and carbonate fluxes in the pelagic eastern Mediterranean: a comparison between sediment trap and surface sediment. Palaeogeogr. Palaeoclimatol. Palaeoecol. 158, 197-213.

Sangiorgi, F., Dinelli, E., Maffioli, P., Capotondi, L., Giunta, S., Morigi, C., Principato, M.S., Negri, A., Emeis, K.C., Corselli, C., 2006. Geochemical and micropaleontological characterisation of a Mediterranean sapropel S5: A case study from core BAN89GCO9 (south of Crete). Palaeogeogr. Palaeoclimatol. Palaeoecol. 235, 192-207.

Scheuvens, D., Schutz, L., Kandler, K., Ebert, M., Weinbruch, S., 2013. Bulk composition of northern African dust and its source sediments-A compilation. Earth Sci. Rev. 116, 170-194.

Schmiedl, G., Mitschele, A., Beck, S., Emeis, K.C., Hemleben, C., Schulz, H., Sperling, M., Weldeab, S., 2003. Benthic foraminiferal record of ecosystem variability in the eastern Mediterranean Sea during times of sapropel S-5 and S-6 deposition. Palaeogeogr. Palaeoclimatol. Palaeoecol. 190, 139-164.

Scrivner, A.E., Vance, D., Rohling, E.J., 2004. New neodymium isotope data quantify Nile involvement in Mediterranean anoxic episodes. Geology 32, 565-568.

Stratford, K., Williams, R.G., Myers, P.G., 2000. Impact of the circulation on saprope formation in the eastern Mediterranean. Glob. Biogeochem. Cycles 14, 683-695.

Tachikawa, K., Roy-Barman, M., Michard, A., Thouron, D., Yeghicheyan, D., Jeandel, C., 2004. Neodymium isotopes in the Mediterranean Sea: Comparison between seawater and sediment signals. Geochim. Cosmochim. Acta 68, 3095-3106.

Tachikawa, K., Piotrowski, A., Bayon, G., 2014. Neodymium associated with foraminiferal carbonate as a recorder of seawater isotopic signatures. Quat. Sci. Rev. 88, $1-13$.

Taylor, S.R., McLennan, S.M., 1985. The continental crust: Its composition and evolution. Blackwell, Malden, pp. 312.

Thirlwall, M.F., 1991. Long-term reproducibility of multicollector Sr and Nd isotope analysis. Chem. Geol. 94, 85-104.

Thunell, R.C., Williams, D.F., 1989. Glacial-Holocene salinity changes in the Mediterranean Sea - hydrographic and depositional effects. Nature 338, 493-496.

Timmermann, A., Friedrich, T., 2016. Late Pleistocene climate drivers of early human migration. Nature 538, 92-95.

Toucanne, S., Mintoo, C.M.A., Fontanier, C., Bassetti, M.A., Jorry, S.J., Jouet, G., 2015. Tracking rainfall in the northern Mediterranean borderlands during sapropel deposition. Quat. Sci. Rev. 129, 178-195.

Tzedakis, P.C., 2007. Seven ambiguities in the Mediterranean palaeoenvironmental narrative. Quat. Sci. Rev. 26, 2042-2066.

Tzedakis, P.C., Frogley, M.R., Heaton, T.H.E., 2003. Last Interglacial conditions in southern Europe: evidence from Ioannina, northwest Greece. Glob. Planet. Chang. 36, 157-170.

Van der Lubbe, H.J.L., Frank, M., Tjallingii, R., Schneider, R.R., 2016. Neodymium isotope constraints on provenance, dispersal, and climate-driven supply of Zambezi sediments along the Mozambique Margin during the past similar to 45,000 years. Geochem. Geophys. Geosyst. 17, 181-198.

Van Dijk, D., Houba, V.J.G., 2000. Homogeneity and stability of materials distributed within the Wageningen evaluating programmes for analytical laboratories. Commun. Soil Sci. Plant Anal. 31, 1745-1756.

Van Santvoort, P.J.M., de Lange, G.J., Thomson, J., Cussen, H., Wilson, T.R.S., Krom, M.D., Ströhle, K., 1996. Active post-depositional oxidation of the most recent sapropel (S1) in sediments of the eastern Mediterranean Sea. Geochim. Cosmochim. Acta 60, 4007-4024.

Venkatarathnam, K., Ryan, W.B.F., 1971. Dispersal patterns of clay minerals in sediments of the eastern Mediterranean Sea. Mar. Geol. 11, 261-282.

Vörösmarty, C.J., Fekete, B.M., Meybeck, M., Lammers, R.B., 2000. Global system of rivers: Its role in organizing continental land mass and defining land-to-ocean linkages. Glob. Biogeochem. Cycles 14, 599-621.

Wehausen, R., Brumsack, H.J., 2000. Chemical cycles in Pliocene sapropel-bearing and sapropel-barren eastern Mediterranean sediments. Palaeogeogr. Palaeoclimatol. Palaeoecol. 158, 325-352.

Weldeab, S., Emeis, K.C., Hemleben, C., Siebel, W., 2002a. Provenance of lithogenic surface sediments and pathways of riverine suspended matter in the Eastern Mediterranean Sea: evidence from ${ }^{143} \mathrm{Nd} /{ }^{144} \mathrm{Nd}$ and ${ }^{87} \mathrm{Sr} /{ }^{86} \mathrm{Sr}$ ratios. Chem. Geol. 186, 139-149.

Weldeab, S., Emeis, K.C., Hemleben, C., Vennemann, T.W., Schulz, H., 2002b. Sr and Nd isotope composition of Late Pleistocene sapropels and nonsapropelic sediments from the Eastern Mediterranean Sea: Implications for detrital influx and climatic conditions in the source areas. Geochim. Cosmochim. Acta 66, 3585-3598.

Wu, J., Liu, Z., Zhou, C., 2013. Provenance and supply of Fe-enriched terrigenous sediments in the western equatorial Pacific and their relation to precipitation variations during the late Quaternary. Glob. Planet. Chang. 108, 56-71.

Wu, J., Böning, P., Pahnke, K., Tachikawa, K., de Lange, G.J., 2016. Unraveling northAfrican riverine and aeolian contributions to central Mediterranean sediments during Holocene sapropel S1 formation. Quat. Sci. Rev. 152, 31-48.

Wu, J., Liu, Z., Stuut, J.-B.W., Zhao, Y., Schirone, A., de Lange, G.J., 2017. North-African paleodrainage discharges to the central Mediterranean during the last 18,000 years: a multiproxy characterization. Quat. Sci. Rev. 163, 95-113.

Yang, S.Y., Jung, H.S., Choi, M.S., Li, C.X., 2002. The rare earth element compositions of the Changjiang (Yangtze) and Huanghe (Yellow) river sediments. Earth Planet. Sci. Lett. 201, 407-419.

Zhao, Y.L., Colin, C., Liu, Z.F., Paterne, M., Siani, G., Xie, X., 2012. Reconstructing precipitation changes in northeastern Africa during the Quaternary by clay mineralogical and geochemical investigations of Nile deep-sea fan sediments. Quat. Sci. Rev. 57, 58-70. 